öz

1917 Ekim Devrimi'nin gerçekleşmesinin ardından Vladimir Tatlin'in sanatı üretimin bir parçası haline getirme düşüncesi ve gerçek malzemeler gerçek mekânda vurgusu ile ürettiği çalışmaları ve 1920 yılında III. Enternasyonal Anıtı'nın Moskova'da sergilenmesinin sonucunda büyük bir kırılma yaratmış, konstrüktivizm aşamalı olarak $\mathrm{S}$.

S. C. B'nin ana akım sanatına ve mimarlığına dönüşmüștür. III. Enternasyonal Anıtı'nı referans olarak kabul eden mimarlar ve sanatçılar tiyatro sahneleri, dekorlar, afişler, çizimler olmak üzere konstrüktivist mimarlğıı ütopya kapsamında değerlendirilen örneklerini tasarlamışlar fakat devrim mimarlığı, konstrüktivistlerin teorilerini yeniden yorumlayan mimarlar tarafından inşa edilmiştir. Çalışmanın amacı; 1922 - 1932 yılları arasında konstrüktivist mimarlı̆ıı mimarlık tarihindeki yerini, ütopya mimarlığı ile uygulanan tasarımlar arasındaki açı farkını, benzerlikleri ve konstrüktivist mimarlığın S. S. C. B'nin toplumsal yaşamındaki karşıı̆ı̆ını siyaset ve sanat arasındaki ilişkiyi esas alarak ortaya koymaktır. Bu amaç doğrultusunda; tektonik, faktura, konstrüksiyon disiplinlerinin sanat siyaset - mekân arasında kurduğu ilişki reel ve ütopya düzleminde yapılan tasarımlar üzerinden incelenmekte, ütopya mimarlığının devrim mimarlığının oluşmasındaki belirleyici rolü üzerinde durulmaktadır. Sosyal yoğunlaştırıcı kavramının mimarlık pratiğindeki yansımaları olan işçi kulüpleri, komün evi, kültür sarayları, gazete binaları, konut yapıları olmak üzere mekân organizasyonu açısından sosyalist düzenin belirleyici etkisi vurgulanmakta, reel ve ütopya düzleminde olmak üzere tasarımların S. S. C. B'nin ihtiyaçlarına cevap verip vermediği sorusu neden - sonuç ilişkisine bağlı olarak tartışılmaktadır.

Anahtar Kelimeler: Sovyet modernizmi, Ütopya mimarlığı, devrim mimarlığı, konstrüktivizm, makine sanatı.

\section{Konstrüktivist Mimarlığın Reel ve Ütopya Düzleminde Mekânsal Incelemesi'}

\author{
(10) Ali Güney Yakar \\ Mimar Sinan Güzel Sanatlar Üniversitesi, Fen Bilimleri Enstitüsü, Mimarlık Tarihi Programı, \\ Istanbul, Türkiye
}

Başvuru tarihi/Received: 07.08.2020, Kabul tarihi/Final Acceptance: 03.11.2021

Extended Abstract

After the 1917 October Revolution, Vladimir Tatlin developed the novel idea of integrating artistic creation into the bigger scope of production. This theory was expressed with emphasize on real materials in real space. The display of the Monument to the Third International in 1920 marked a turning point and constructivism became the USSR's main stream artistic and architecture style. Taking the Monument to the Third International as a reference, architects and artists designed what have been deemed as utopian examples of constructivist architecture using theater stages, decorations, posters, and drawings. However, revolutionary architecture was built on the efforts of the architects who reformulated constructivist approach.

Anatoli Lunacharsky who was appointed as the head of Narkompros, assigned avant-garde artists to institutions affiliated to Narkompros due to their support for the revolution. Tatlin, who was appointed as the head of the Moscow Fine Arts Department in 1919, emphasized that the distinction between plastic arts should disappear and the artist should have an engineer formation in his writings. The fact that Vkhutemas's education program is immanent to Tatlin's ideas, and his assignment to design Monument to the Third International within the scope of Lenin's Monumental Program gave Tatlin a chance to apply his ideas in practice and provide a basis for the constructivism movement to rise. Design of Monument to the Third International led to the adoption of Tatlin's ideas by different artists and architects, afterwards First Working Group of Constructivists was formed in 1921. Constructivists had declared the tectonic style, factura and construction disciplines in which the theory of constructivist architecture is shaped in their programs, in which they refer to historical materialism and scientific socialism.

Monument to the Third International, the first monument of machine art, is a living organism where socialist propaganda is carried out, which overcomes the barrier of time and space due to its technological equipment, and contains spaces where socialist culture can be experienced. The monument, where tectonic style, factura and construction disciplines correspond, influenced names such as Alexander Rodchenko, Lyobov Popova, Alexander Vesnin, as well as Gustav Klutsis who completed his education in Vkhutemas, Naum Gabo who criticized the constructivist theories, El Lissitzky whose work was heavily influenced by Suprematism and Yakov Chernikhov, who designed technically advanced examples of constructivist architecture on the utopia plane. Nevertheless, designs that are impossible to implement created by the constructivists without considering the objective conditions of the USSR, the technological possibilities of the period and the needs of the society show that the contradiction of constructivists' discourses and architectural practices.

In the period between 1922 and 1925, the practice of constructivists was proven to be applicable and the constructivist theory was reconsidered with a realistic approach. The Vesnin Brothers' Palace of Labour design, which is essential for the development of constructivist architecture, is a design where tectonic, factura and construction disciplines correspond, the use of industrial materials is emphasized, reflects the socialist culture with analogy, and most importantly, it can be applied with the technological possibilities of its age. Just as Monument to the Third International is the cornerstone of the development of constructivist architecture on the utopia level, the design of the Palace of Labour, is also a touchstone in the real plane. Another essential development was Ginzburg's work Style and Epoch that reconsiders the theory of constructivist architecture and puts it on a real plane. Constructivist architecture was introduced to the USSR with the establishment of OSA in 1925 under the leadership of Vesnin and Ginzburg. Between 1925 and 1932/1934, the constructivists, who aimed to organize the collective life in a world where there was no hierarchy, and to convey the achievements of the proletarian culture and socialist order to the society through architecture, were based on the concept of social condensor. They have succeeded in building workers' clubs, palaces of culture, commune houses and residential buildings in different regions of the USSR.

The aim of this paper is to shed light on the role of constructivist architecture within the greater context of architectural history, the difference and similarities between Utopian architecture and applied designs, and the application of constructivist architecture in communal living practices of the USSR. Analyzing the relationship between arts and politics is critical to this discussion. With this aim, the relation of arts-politics-space, created by the disciplines of tectonic unites, faktura, and construction, is evaluated through real and utopian designs. The decisive role that the utopian architecture played in the formation of a revolutionary architecture style is elaborated on. Therefore, the question is posed as to whether the real and utopian designs met the needs of the USSR through the cause and effect relation.

Keywords: Soviet modernism, Utopian architecture, revolutionary architecture, constructivism, machine art.
This work is licensed under a Creative Commons Attribution-No 


\section{Giriş}

1917 Ekim Devrimi gerçekleşmeden önce farklı avangard sanat toplulukları içinde yer alan Vladimir Tatlin, sanatın belirli bir zaman ve mekân içine sıkıştırılması düşüncesine karşı çıkmış, 1913 yılında endüstriyel malzemeler kullanarak ilk konstrüktivist üretimler olarak nitelenen rölyef çalışmalarını tamamlamıştır. Ekim Devrimi'nin gerçekleşmesinin ardından Rusya coğrafyasında sosyalist düzenin inşa sürecinin başlaması ile diğer avangard sanatçılar gibi Tatlin de devlet kurumlarında görevlendirilmiş, bu dönemde sanatına sosyalist bir kimlik kazandırmış, plastik sanatlar arasındaki ayrımın ortadan kald1rılması gerektiğini savunmuş ve mimarlık üzerine yazılar kaleme almıştır. 1920 yılında Lenin'in Anıtsal Programı kapsamında Anatoli Lunaçarski tarafından görevlendirilmesinin ardından Tatlin Kulesi olarak da bilinen III. Enternasyonal Anıtını tasarlamış ve fikirlerini pratikte uygulama şansı bulmuştur.

Aynı yıl III. Enternasyonal Anıtı Rusya Komünist Partisi kadroları tarafından ağır bir biçimde eleştirilmesine karşın sanatçıları ve mimarları etkilemiş, Tatlin'in fikirlerini benimseyen mimarlar ve sanatçılar kendilerini konstrüktivist olarak tanımlamaya başlamış ve 1922 yılında Sovyet Sosyalist Cumhuriyetler Birliği’nin kuruluşuna uzanan süreçte konstrüktivizmin teorik alt yapısı oluşmaya başlamıştır. 1922-1932/1934 y1lları arasında konstrüktivizm, devrimin sanatını ve mimari yaklaşımını şekillendirmiş ancak mimarlık hususunda bu gelişimin hayata geçmesi ve uygulanması, konstrüktivistlerin teorilerinin gerçekçi bir perspektifle yeniden ele alınmasıyla mümkün olmuştur. Bu bağlamda önce konstrüktivist sanatçılar dönemin konjonktüründen, S.S.C.B'nin ekonomik imkânları ve nesnel koşullardan bağımsız, uygulanması imkânsız tasarımlar yapmışlar ve ideal olanı aramışlardır. Konstrüktivist mimarlığın teorik zemini dolayısıyla tektonik, faktura ve konstrüksiyon disiplinlerinin oluşturduğu üçgen içinde şekillenen ütopya mimarlığı kapsamında nitelendirilen tasarımlar, uygulanmamalarına karşın devrim mimarlığını inşa etmekle görevlendirilen mimarların gerçekleştirdikleri reel düzlemde inşa edilen mimari yapıların tasarımlarının karakterini oluşturmuştur.

Tektonik, faktura ve konstrüksiyon disiplinlerinin hem ütopya düzleminde hem de reel düzlemde nitelendirilen tasarımlarda karşılık bulmasının yanı sıra devrim mimarlığını ve konstrüktivist mimarlığ 1 tanımlanabilir yapan en önemli unsur sosyalist düzen veya sosyalist düzeni yansitan ilk yapılar olmasıdır. Sovyet modernizmi kapsamında değerlendirilen konstrüktivist yapılar aracılığıyla kolektif yaşam, devlet ile işçi sınıfı arasındaki şeffaflık, sınıf farkının olmadığı bir toplum için hayat kurgulanırken kolektifi oluşturan bireylerin ihtiyaçları da gözetilmiştir. Devrim mimarlığının inşasında görev alan konstrüktivistler, sosyal yoğunlaştırıcı kavramından yola çıkarak işçi kulübü, kültür sarayı, emek sarayı, komün evi gibi konseptler üreterek işçi sınıfının sadece hayatta kalmasını sağlayan değil çalışma hayatında ve sosyal yaşamında kendini geliştirebileceği, kolektif yaşamın bir parçası olabileceği mekânlar yaratmışlardır.

Ütopya düzleminde ve reel düzlemde değerlendirilebilecek tasarımlar arasında hiç kuşkusuz bir açı farkı bulunmaktadır. $\mathrm{Bu}$ açı farkı değerlendirilirken S.S.C.B'nin nesnel koşulları, imkânları, dönemin konjonktürü ve işçi sınıfının hayati ihtiyaçları ile birlikte 1917 Ekim Devrimi öncesinden sonrasına Tatlin'in fikirlerinde yaşanan dönüşüm, Rusya Komünist Partisi'nin program1, RKP'nin konstrütkvistler dahil olmak üzere avangard sanatçılara bakış açısı ve politikaları da konstrüktivist mimarlı̆̆ın gelişimi hususunda göz önünde bulundurulmalıdır. Diğer yandan konstrüktivist mimarlığın altında ütopya düzleminde ve reel düzlemde değerlendirilen üretimler birbirinden bağımsız ve kopuk değil organik bir ilişki içerisindedir. Sanılanın aksine reel düzlemde inşa edilen konstrüktivist yapıların ütopya mimarlığ ile ilişkisi modern mimarlıkla olan ilişkisinden daha kuvvetlidir. Her ne kadar iki düzlemde tasarlanan yapılar arasında açı farkı bulunsa da söz konusu tasarımları

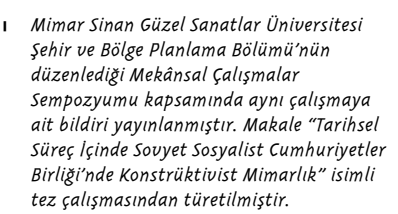

Mimar sinan Güzel Sanatlar Üniversitesi sehir ve Bölge Planlama Bölümü’nün düzenlediği Mekânsal çalışmalar ait bildiri yayinlanmıstir. Makale "Tarihsel sureç lçinde Sovyet Sosyalist Cumhuriyetler tez çalışmasından türetilmiştir. 
ortaya koyan sanatçılar ve mimarlar aynı teorik zeminden beslenmiş, aynı kaygıları paylaşmış, üretimlerini sosyalist düzende yaşayan insanlar için yapmışlardır.

$\mathrm{Bu}$ çalışmanın amacı; III. Enternasyonal Anıt1, Tatlin'in ve Konstrüktivistlerin Birinci Çalışma Grubu'nun fikirleri ile birlikte ütopya mimarlığında karşılık bulan tektonik, faktura ve konstrüksiyon disiplinlerini referans alarak ütopya mimarlığının gelişimini, mekân kurgusunu inceleyerek konstrüktivist mimarlığın reel düzlemde nasıl bir seçeneğe dönüştüğünü irdelemek; devrim mimarlığının inşasında görev alan konstrüktivistlerin sosyalist düzene içkin ürettikleri yeni konseptler ve yarattıkları mekânlar ile ütopya mimarlığı arasındaki ilişkiyi ele almak ve konstrüktivist mimarlığın mimarlık tarihindeki yerini belirleyen unsurları ortaya koymaktır.

\section{Sosyal Realizm ile Rus Avangardinın İdeolojik Çatışması ve Tatlin'in Sanatı}

S.S.C.B'de konstrüktivist mimarlığın reel ve ütopya düzlemindeki evrimini, devrim mimarlığının nasıl şekillendiğini incelemeden önce konstrüktivizm akımının yükselişini, Rusya Komünist Partisi ile avangard sanatçılar arasındaki teorik ve ideolojik çatışmanın ortaya koyduğu sorunsalın özünü ele almak için devrim öncesinde Rus Sanatı'nda yaşanan değişimden bahsetmek gerekmektedir.

19. yüzyılın ikinci yarısında feodal düzenin hâkim olduğu Rus İmparatorluğu'nda, Avrupa halklarının 1789 Fransız Devrimi ve Endüstri Devrimi ile elde ettiği kazanımlarından söz edebilmek mümkün değildir. Rus İmparatorluğu'nda serflik oldukça geç bir tarihte, 1861 yılında kaldırılmış ve kapitalist üretim ilişkilerinin nüveleri ortaya çıkmıştır (Carr, 2011). Bu dönemde serfliğin kaldırılmasının sonucunda mülkiyetin toprak sahiplerinin elinden alınıp köylülere verilmesi gerektiğini savunan, köylü sınıfinı Rus İmparatorluğu'nu devirmek için itici bir güç olarak gören Narodnik Hareket ülkede etkisini hissettirmeye başlamıştır.

Bu hareketin en önemli kalemşörlerinden biri olan Nikolay Çernişevski'nin 1855 yılında kaleme aldığı Estetik İlişkileri çalışması ise yaşanan siyasi gelişmelerin ardından 1863 yılında St. Petersburg'daki sanat akademisinde eğitim alan 14 öğrencide karşılık bulmuştur (Bowlt, 2017). Akademinin dayattığ sanat anlayışını reddeden öğrenciler akademiyi terk etmiş, Rus köylüsünün sorunlarını ve gündelik yaşamlarını konu alan resimler yapmaya başlamışlardır. 1871 yılında farklı sanatçıların katılımıyla Gezginler adını alan grup Rusya'nın farklı bölgelerinde sergiler düzenlemiş, Rus toplumuna ve köylülere çalışmalarıyla ayna tutarak bilinç taşımayı hedeflemişlerdir. Gezginlerin sosyal realizmi veya Rus sosyal realizmi 1890'lı yıllara kadar Rus Sanatını domine etmiştir.

Bu noktada 1917 Ekim Devrimi'nin ardından neden RKP kadrolarının büyük çoğunluğu tarafindan sosyal realizmin benimsendiğinin anlaşılması için Sanatın Gerçeklikle Estetik İlişkileri Çalışması'nın özünde anlatılanı vurgulamak gerekmektedir. Çernişevski çalışmasında dönemin sanatına hakim olan Hegel'in ideal güzellik anlayışı reddetmekte aristokrasinin hegemonyasında üretilen sanatın Rus köylüsünün yaşamında karşılı̆̆ olmadığı gibi Rus halkının ağır yaşam ve çalışma koşullarından kaçabileceği bir yanılsama sunmasına bağlı olarak sanatçının görevinin halka empoze edilen yanılsamayı ortadan kaldırarak gerçekliği var olduğu haliyle aktarmak olduğunu ifade etmektedir (Çernişevski, 2012). Buna koşut olarak sosyal realizmi benimseyen sanatçılar için sanatın, siyasetin bir aracı olduğu, sanatın siyasi düzenden bağımsız düşünülemeyeceği açıktır.

Diğer yandan 1890'lı y1llarda St. Petersburg Sanat Akademisi'nde eğitim alan Alexander Benois öncülüğündeki sanatçı topluluğu sosyal realizmin Rus sanatını domine etmesine karşı çıkarak ütopyacı sosyalist Saint Simon'un avangard söylemiyle benzer bir biçimde sanatçıyı toplumu oluşturan sınıflarla ilişkisinden bağımsız olarak konumlandırmış ve sanatın bulunduğuna inandıkları özerk alan üzerinden sanatçının dönüştürme gücünü tanımlamışlardır. Batı sanatını, modern kültürü Rusya coğrafyasına tanıtma görevini üstlenen ekip; 1898 yılında Sanat Dünyası Dergi- 
si'ni kurmuş, Avrupalı ve Rus sanatçıların çalışmalarından oluşan karma sergiler düzenlemiş, 1903 yılında hareketin amacına ulaştığını ifade ederek Sanat Dünyası Dergisi'nin yayın hayatını sonlandırmıştır. 1904 - 1913 yılları arasında Sanat Dünyası Dergisi'nin etkisinde sembolizm, primitivizm, rayonizm, kübo - fütürizm akımlarından etkilenen sanatçılar Altın Post, Mavi Gül, Tatlin'in de yer aldığı Eşek Kuyruğu, Karo Valesi isimli kurdukları bağımsız avangard sanat toplulukları ile sergiler düzenlemişlerdir (Gray, 2000). Bu bağlamda sosyal realizm ile avangard sanatın teorik zeminlerinin taban tabana zit olduğunun vurgulanması gerekmektedir.

1913 yılında Picasso'nun Paris'te düzenlediği sergisini ziyaret etme firsatı bulan Tatlin, Picasso'nun Gitar isimli kübik konstrüksiyonundan etkilenmiş ve aynı yıl Moskova'ya dönmesinin ardından teneke, metal levha ve duvar kâğıdından oluşan Şişe isimli çalışmasını tamamlamıştır (Nisbet, 2010). Tatlin'i etkileyen husus yaşadığ 1 döneme kadar süregelen sanat üretiminden bağımsız olarak gitar enstalasyonunun belirli bir zamanın ve mekânın dışına çıkarak bireyin var olduğu zamana ve mekâna taşabilmesidir. Bu bağlamda Tatlin çağı sembolize eden endüstriyel malzemeleri kullanarak oluşturduğu köşe rölyef çalışmalarını ilerleyen yıllarda tamamlamış, sanatı gerçek mekâna taşıyarak izleyici ile sanat eseri arasında tanımlanamayan soyut mesafeyi ortadan kaldırmıştır. Tatlin sanatı gündelik hayatın bir parçası haline getirmesine karşın diğer avangard sanatçılar gibi sanatı siyasetten, toplumun içinde bulunduğu nesnel koşullardan bağımsız olarak özerk bir alanda konumlandırmıştır.

Bu durum Tatlin'in 1917 Ekim Devrimi öncesinde sanatı doğrudan veya dolaylı olarak siyasetle ilişkilendirmediğini gösterdiği gibi konstrüktivist mimarlığın ütopya düzleminde değerlendirilen örneklerinin neden Sovyet halkının ihtiyaçları gözetilmeden, nesnel gerçeklik referans alınmadan üretim yapıldığı, neden ideal olanın arandığı ve RKP'nin avangard sanatçılar ile konstrüktivistlere eleştiriler getirdiği sorularını cevaplamaktadır.

\section{Enternasyonal Anitı ve Konstrüktivizm Akımının Yükselişi}

1917 Ekim Devrimi’nin gerçekleşmesinin ve R.S.F.S.C '2'nin anayasasının kabul edilmesinin ardından RKP'nin süratle devletin kurumlarını inşa ettiği, 1918-1922 yılları arasında Rus İç Savaşı'nın yaşandığı ve Savaş Komünizmi 3 politikasının uygulandığ dönemde sanılanın aksine avangard sanatçılar RKP'nin desteğini almamış partinin öncü kadroları ve diğer sanat örgütlerinin eleştirilerinin hedefi haline gelmiştir (Jangfeldt, 1976). 1920 yılında Lenin'in Vkhutemas'1 ziyaret ettiği sırada öğrencilere "Okulunuzda ne yapıyorsunuz, fütüristlerle savaşıyorsunuz, öyle umuyorum." sorusunu sormas1, 1921 y1lında avangard sanata şiddetle karşı çıkan ve sanatta realizmi savunan AKhRR 4'nin kurulmasına doğrudan destek vermesi, Lenin'in düşüncelerini şeffaf bir biçimde ortaya koymaktadır (Barooshian, 1976, s. 205). Bununla birlikte III. Enternasyonal Anıt1 1920 yılında sergilendiğinde Troçki “...Dünya Halk Komiserleri Konseyi için spiral beton tapınağa oturan bir bira şişesi inşa etmek istiyor..." ifadesiyle Tatlin'i eleştirmiştir (Rowell, 1978, s. 107). RKP kadroları tarafindan avangard sanatçıların genelleyerek fütüristler olarak tanımlanması, RKP'nin öncü kadrolarının avangard sanatçılara yaptıkları eleştiriler konstrüktivizm akımının nasıl yükseldiği sorusunu ortaya çıkarmaktadır.

Konstrüktivizm akımının yükselişinde belirleyici unsurlar Anatoli Lunaçarski'nin Narkompros' ${ }^{5}$ un başına getirilmesi, Tatlin'in kaleme aldığ 1 yazılarında sanatı konumlandırdığı düzlemi değiştirerek sosyalist bir kimlik kazandırmaya çalışması, Vkhutemas'in kuruluşu ve III. Enternasyonal Anıtı'nın sergilenmesi olarak sıralanabilir. Lunaçarski avangard sanatçıları devrim sürecine koşulsuz destek vermeleri nedeniyle Narkompros'a bağlı kurumlarda görevlendirmiş, Tatlin 1919 yılında Moskova Güzel Sanatlar Departmanı'nın yöneticisi olmuştur (Lunaçarski, 2004). Tatlin bu dönemde Kolektif Yaratıcılıkta Bireysel İnisiyatif yazısında sanatçı - üretici işçinin doğrudan ülkenin siyasetinde, ekonomik kalkınmasında, endüstriyel üretiminde ve

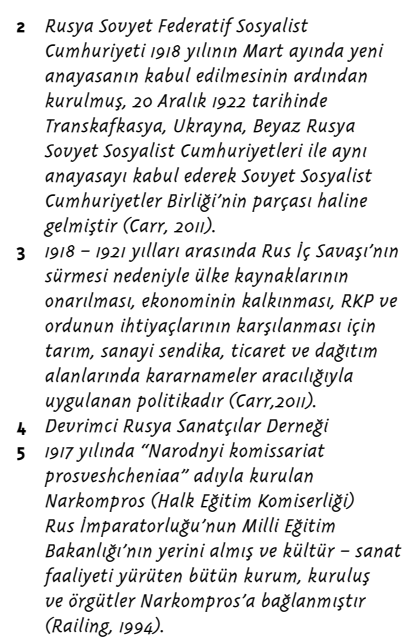

2 Rusya Sovyet Federatif Sosyalist Cumhuriyeti 1918 yilinin Mart ayinda yeni asanin kabul edilmesinin ardindan Transkafkasya, Ukrayna, Beyaz Rusya sovyet Sosyalist Cumhuriyetleri ile aynı anayasayı kabul ederek sovyet sosyalist cumhuriyetler Birliği'nin parçası haline 1918 - 1921 yılları arasında Rus lç Savaşı'nı onarılmasi, ekonominin kalkınması, RKP ordunun ihtiyaçlarının karssılanması için tarım, sanayi sendika, ticaret ve dağıtım alanlarında kararnameler aracıllı̆ılla Deurimci Rusya sanatslar Dernegi 1917 yilinda "Narodnyi komissariat prosveshcheniaa" adıyla kurulan Narkompros (Halk Eğitim Komiserliği) Bakanlığı'nın yerini almış ve kültür - sanat ve örgütler Narkompros'a (Railing, 1994). 
Şekil: I

III. Enternasyonal Anitı (Rickey, G. (1967). Constructivism: Origins and. Evolution. New york: Braziller).
61920 yilında Narkompros'a bağlı olarak Yüksek sanat ve Teknik Atölyeleri (Vkhutemas); mimarlik, resim, heykel, grafik, tekstil, seramik, metal ve ahşap iş̧iliği olmak üzere sekiz üretim departmanını kapsamaktaydı (Bokov, 2014).

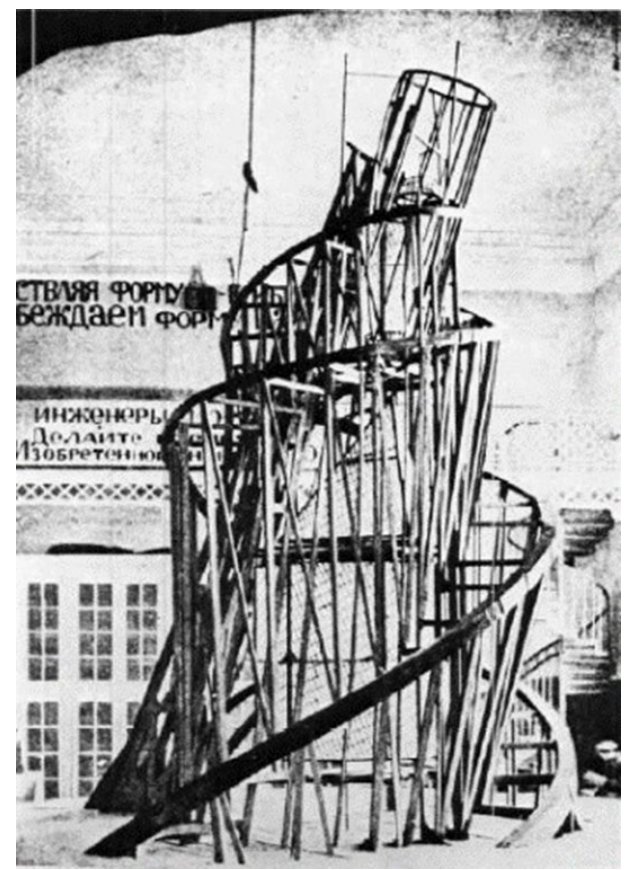

toplumsal yaşantısında sorumluluk alması gerektiğini; Önümüzde Çalış isimli yazısinda ise mimarlık, heykel ve resim arasındaki ayrımın ortadan kalkması gerektiğini, bireysel yaklaşımların sonucunda absürd mimari formların ortaya çıktığını, 1918 y1lına kadar malzeme, hacim ve konstrüksiyon üzerine yaptığı çalışmaların demir ve camın kombinasyonunun yapılmasını sağladığını, demir ve camı modern klasisizmin materyalleri olarak tanımlandığını, 1920 yılına uzanan süreçte yapılan araştırmaların sanatçıları yeni icatlara yönelttiğini ifade etmiştir (Cooke ve Ageros, 1991). Tatlin fikirlerini pratiğe dökme şansını Lunaçarski'nin Lenin'in Anıtsal Programı kapsaminda III. Enternasyonal Anıtı'nı tasarlama görevini vermesi ile yakalamıştır (Şekil 1).

Lenin III. Enternasyonal Anıtı'nın sosyalist düzenin propagandasını doğrudan yapan, 1917 Ekim Devrimi sürecindeki kahramanlığı vurgulayan, işçi sınıfını ve köylüyü esas alan bir anıt olmasını talep etmiş, Tatlin ise sosyalist düzeni temsil edecek bir anitta bireylere, kahramanlara yer olmadığını ifade ederek soyut ideal bir yapı tasarlamıştır (Rowell, 1978). Bu bağlamda Tatlin'in fikirleri ile RKP arasındaki çatışma S.S.C.B'nin 1934 yılında avangard programı sonlandırdığı süreçte değil
S.S.C.B kurulmadan önce başlamıştır. Buna karşın III. Enternasyonal Anıtı RKP tarafından eleştirilmesine rağmen nitelikleri dolayısıyla kırılma yaratmıştır.

Eiffel Kulesi'nden üç kat yükseklikte olduğu hayal edilen yapı cam küp, koni ve silindirden oluşmakta yapının gövdesini desteklemesi amaciyla demir karkas etrafinı sarmaktadır. Derslerin, kongrelerin ve konferansların düzenleneceği cam silindir yılda bir kere, yürütme faaliyetlerinin yapıldığı koni ayda bir kere, bilgi merkezi olarak kullanılacak küp günde bir kere kendi etrafinda dönecek şekilde tasarlanmıştır (Gray, 2000). Anıta dev ekranlar, hoparlörler, projeksiyonlar ve radyo olmak üzere teknolojik donanımın eklemlenmesi ön görülmüş; bültenlerin, haberlerin, manifestoların halka duyuracak, sloganları gökyüzüne yansitacak ve yayın yapacak, cam ve demirden oluşan bir kule inşa etmek hedeflenmiştir.

III. Enternasyonal Anıtı inşa edilememesine karşın Tatlin tasarımıyla sanat - mimarlık - siyaset arasında güçlü bir ilişki kurmuş, aynı y1l kurulan Vkhutemas ${ }^{6}$ 'n eğitim programında yer alan plastik sanatlar arasındaki ayrımın ortadan kaldırılması, kaliteli endüstriyel üretim için sanatçıların mühendis formasyonuna sahip olması ve üretim sürecinin bir parçası olmak üzere yetiştirilmeleri gerektiğine dair maddelerin yer aldığı programın ilgili kurul tarafından kabul edilmesi, Tatlin'in fikirlerinin Vkhutemas'ta karşılık bulmasını sağlamıştır. 1921 y1lında kurulan Konstrüktivistlerin çalışma grubunda ise Vkhutemas'ta eğitimci olarak görev yapan Alexander Vesnin, Lyobov Popova, Alexei Gan ve Alexander Rodchenko yer almış, yayınladıkları programlarında tarihsel materyalizm ve bilimsel sosyalizmin esas alınması, sanatın hayatla iç içe olması ve metafizik yaklaşımların terk edilmesi gerektiği vurgulanmıştır (Bann, 1990). Programın üçüncü maddesinde konstrüktivist bir tasarımı tanımlanabilir kılan tektonik tarz, faktura ve konstrüksiyon disiplinleri "Tektonikler bir yandan komünizmin özelliklerinden diğer yandan endüstriyel malzemenin yararlı kullanımından temperlenir ve 
şekillendirilir. Faktura çalışılmış malzemenin veya organizmanın sonuçlanan yeni biçiminin organik ifadesidir. Bu nedenle grup fakturayı konstrüksiyonu engellemeden veya tektonikleri kısıtlamadan bilinçli çalışılmış ve elverişli bir şekilde kullanılan malzeme olarak göz önünde bulundurur. Konstrüksiyon, konstrüktivizmin organizasyonel fonksiyonu olarak anlaşılmalıdır." ifadeleri ile açıklanmıştır (Harrison ve Wood, 2013, s. 317).

Daha açık bir ifade ile tektonik veya tektonik tarz ideolojik propaganda/sosyalist propagandanın yansıması, faktura tasarımı meydana getiren endüstriyel materyal ve malzemelerin bilinçli kullanımı, konstrüksiyon ise tasarımın estetik ve fonksiyonel olarak somutlaşmış biçimidir. Söz konusu üç disiplin hem ütopya hem de reel düzlemde konstrüktivist mimarlığın teorisinin zeminini oluşturmakla birlikte tasarımların karakterini yansıtmaktadır. Diğer yandan üç disiplinden herhangi birinin gözetilemediği bir tasarım konstrüktivist olarak tanımlanamamakta, tasarımın insanla ve gündelik yaşamla kurduğu ilişki kopmakta ve anlamsızlaşmaktadır. Bu bağlamda Konstrüktivist mimarlığın teorisinin, pratiğinin, tektonik, faktura ve konstrüksiyon disiplinlerinin karşılık bulduğu III. Enternasyonal Anıtı'nın niteliklerinin ötesinde irdelenmesi gerekmektedir.

Öncelikle Tatlin'in III. Enternasyonal Anıtı sadece anıtsal bir yapı değil, makine sanatının ilk örneği olan dev bir aygıt, zaman ve mekânla birlikte yaşayan canlı bir organizmadır. Tıpkı Tatlin'in köșe rölyefleri gibi III. Enternasyonal Anıtı da zaman ve mekân engelini ortadan kaldırmıştır. Köşe rölyeflerinin belirli bir zamanın dışına taşarak insanın bulunduğu mekânda var olabilmesini sağlayan endüstriyel malzemeler, III. Enternasyonal Anitında gelişmişlik düzeyini ve çağı sembolize eden materyaller olarak mimari yapıda makine estetiğginin somutlaşması amacıyla kullanılmıştır. Fakat köșe rölyeflerinden farklı olarak III. Enternasyonal Anıtına eklemlenen teknolojik donanım, mimarl1ğın hapsolduğu zaman ve mekân engelinin aşılmasını sağlamıştır.
1917 Ekim Devrimi'nin ve sosyalist kültürün sembolü olarak tasarlanan anitsal yapının aynı zamanda haberleri, gündelik yayınları ve sosyalist propagandayı doğrudan halka taşıyacak, topluma hizmet eden bir araç olması, yapının canlı bir organizmaya dönüşerek zaman ve mekân engeline takılmadan sürekli ve geniş çapta insanla temas kurabilmesi anlamına gelmektedir. Buna binaen gündelik yayınların, haberlerin ve yapılan propagandanın niteliği zamanla değişmesine karşın yapının işlevini kaybetmeyeceğini, yap1 var olduğu sürece insanla, toplumla ve işçi sinıfiyla temas kurmaya devam edeceğini ifade etmek mümkündür.

İkinci önemli husus ise III. Enternasyonal Anıtı'nın mekân organizasyonunun toplantıların, derslerin ve konferansların da yapılabileceği şekilde kurgulanmasıdır. Bu durum III. Enternasyonal Anıtı'nın büyük kütlesi ve sahip olduğu teknolojik donanım ile sadece ideolojik propaganda yapan dev bir makine değil aynı zamanda işçi sınıfının ve Sovyet toplumunun sosyalist kültürü deneyimleyebileceği bir yapı olduğu anlamına gelmektedir. Dolayısıyla sosyalist propaganda ve kültür, makine estetiği, teknolojik donanım, endüstriyel malzemeler ve tasarımın organizasyonu olmak üzere III. Enternasyonal Anıtını ve konstrüktivist mimarlığın ilk örneğini oluşturan bileşenler tektonik tarz, faktura ve konstrüksiyon disiplinlerinde karşıllk bulmakta ve üç disiplin ile birlikte anlamlı bir bütünü oluşturmaktadır.

\section{Ütopya Düzleminde Konstrüktivist Mimarlık}

III. Enternasyonal Anıt1, Vkhutemas'1n eğitim program1, Tatlin'in yazıları, Konstrüktivistlerin Birinci Çalışma Grubu'nun programı ve Alexei Gan'in 1922 yılında Konstrüktivizm isimli yayınlanan çalışmas1 reel ve ütopya düzleminde olmak üzere konstrüktivist mimarlığın ana akım mimarlığa dönüşmesinde belirleyici olmuş, konstrüktivist mimarlık Vkhutemas ve Moskova merkezli olarak S.S.C.B coğrafyasına yayılmıştır. Ancak Tatlin'in fikirlerinin diğer avangard sanatçı ve mimarların tasarımlarına olan etkisinin 1921-1922 yılları

174 Sayı 34, Kasım 2021 

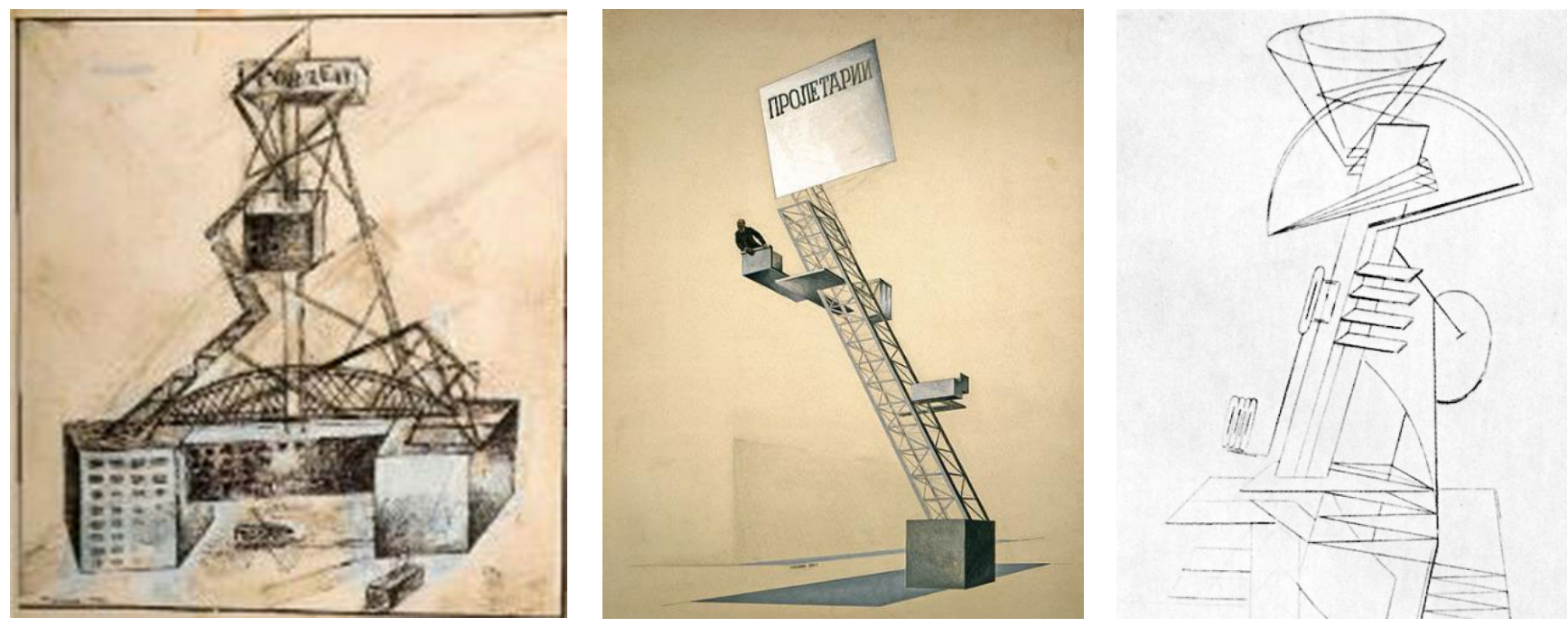

sekil: 2

Sovyet Vekil Binası (Margolin, V. (2012).

Ütopya Mücadelesi. Istanbul: Espas Kuram sanat Yayın(ari).

şekil: 3

Lenin Tribünü (Margolin, V. (2012). Ütopya Mücadelesi. Istanbul: Espas Kuram Sanat yayın(ari).

sekil: 4

Radyo Kulesi (Margolin, V. (2012). Ütopya Mücadelesi. Istanbul: Espas Kuram Sanat yayın(ari).
71919 yilinda kurulan "Resim, Heykel ve Mimari Sentez" isimli sanatçı ve mimarlardan oluşan topluluktur. (Margolin, 2012). arasında konstrüktivistlerin örgütlendiği ve konstrüktivizmin teorisinin şekillendiği dönemde değil III. Enternasyonal Anıtı'nın sergilenmesinin ardından başladığını söylemek mümkündür. Bu bağlamda III. Enternasyonal Anıtı ütopya mimarlığının gelişimi hususunda hem mihenk taşı hem de referans noktasidir.

Tatlin'in çalışma arkadaşı olan Alexander Rodchenko konstrüktivizm akımının ikinci öncü ismi olarak kabul edilmektedir. Ekim Devrimi'nin gerçekleşmesinin ardından Tatlin gibi Lenin'in Anıtsal Programı kapsamında görevlendirilen Rodchenko, 1919 y1lında Zhıvskulptarkh7'a üye olmuş ve ilk mimari tasarımlarını bu dönemde tamamlamıştır (Margolin, 2012). 1920 yılında III. Enternasyonal Anitı'nın sergilenmesinin ardından ise Tatlin'in fikirlerinin Rodchenko'nun tasarımları üzerindeki etkisini Sovyet Vekil Binası'nda görmek mümkündür (Şekil 2). Kule biçiminde yükselen yapının betonarme zemini vekillerin çalışma odası olarak kurgulanmış, uzamsal bağlantılar kurularak teknolojik detaylar yapının üst kısmında kentin farklı noktalarından görülebileceği şekilde yerleştirilmiştir. III. Enternasyonal Anitı gibi Sovyet Vekil Binası'nda da propaganda sosyalist düzeni çağrıştıran imgeler veya sloganlarla değil çağının ötesinde bir teknoloji ile vurgulanmıştır. Sovyet Vekil Binası'nda tektonik, faktura ve konstrüksiyon disiplinleri ile somutlaşan konstrüktivist karakter oldukça belirgindir.
Rodchenko'nun ardından III. Enternasyonal Anıtı'ndan ve Tatlin' in fikirlerinden etkilenen bir diğer ismin El Lissitzky olduğunu söylemek mümkündür. 1919 yılında Vitebesk Sanat Okulu'nda Malevich ile birlikte çalışma firsatı bulan Lissitzky'nin resim ile geleceğin mimarisi arasında ara duraklar olarak tanımladığı Proun tasarımlarının ilk örnekleri süprematizm etkisindedir (Nakov, 1986). Ancak III. Enternasyonal Anıtı'nın sergilenmesinin ardından Lissitzky Tatlin'den etkilenmiş ve 1920 yılında Lenin Tribünü'nü tasarlamıştır (Şekil 3). Tribün gri renkteki bir küp kaide üzerinde çapraz bir açı ile gökyüzüne doğru yükselmekte, yapıda endüstriyel malzemeler ve çağının ötesindeki teknolojik donanım vurgulanmakta, yapının üzerinde yer alan dev ekran, görsel olarak çapraz açıyla yükselen yapının dengesini sağlamaktadır.

Tribün üzerinde konuşma yaparken tasvir edilen Lenin'in arkasında yer alan dev ekranda proletarya yazmakta, propaganda işçi sınıfı vurgusu, teknolojik donanım, endüstriyel malzemeler ve 1917 Ekim Devrimi'nin öncüsü Lenin aracıllğıyla yapılmaktadır. III. Enternasyonal Anıtı ve Sovyet Vekil Binası'nda da olduğu gibi teknolojik donanım yükselen yapının üst kısmına eklemlenmiştir. Lenin konuşma yaptığı hayal edilen kitlenin tamamına hakim konumdadır. Bu bağlamda El Lissitzky'nin kariyeri süresince yaptığı tasarımlar göz önünde bulundurulduğunda Lenin Tribünü tasarımı konstrüktivist mimarlığ 
oluşturan tektonik, faktura ve konstrüksiyon ilişkisine bağlı kalarak olușturulmuş istisnai bir çalışmadır. Öte yandan sanatla siyaset arasında doğrudan bir bağ kurdukları, zamanı değil hacmi referans aldıkları için konstrüktivistlerin teorilerine karş1 çıan Naum Gabo'nun ise III. Enternasyonal Anıtı'ndan etkilenerek Serpuchov Köyü için multifonksiyonel radyo kulesi tasarlaması 1920 yılında Tatlin'in yarattığı etkiyi kanitlar niteliktedir (Sekil 4).

Konstrüktivistlerin 1922-1923 y1lları arasında etkisini hissettirmesiyle birlikte ütopya düzleminde konstrüktivist mimarlığın aşamalı gelişim süreci başlamıştır. Vkhutemas'ta eğitimini tamamlayan, kariyeri süresince propaganda afişleri tasarlayan konstrüktivist Gustav Klutsis' in 1924 yılında tasarladığı Ajistasyon Platformları söz konusu gelişime örnek oluşturmaktadır. Endüstriyel malzemelerden oluşan, dev ekranlara, radyo ve hoparlörlere sahip kiosk biçimindeki Ajitsyon Platformları gündelik kent yaşamının bir parçası olan, sosyalist düşüncenin yayınlar aracılığıyla halka taşınmasını hedefleyen salt bir propaganda aracidır.

Ajitasyon Platformları anıtsal boyutta değil ortalama bir insan boyutunda olup kentin farklı noktalarında konumlandırılacağı ön görülerek tasarlanmıștır (Sekil 5). III. Enternasyonal Anıtı'ndan farklı olarak Ajitasyon Platformlarının referans noktası kitleler değil kitleleri oluşturan bireyler ve küçük topluluklardır. Propagandanın ölçeğine, ulaşı1lmak istenilen özne veya öznelere bağlı olarak III. Enternasyonal Anıtı'na kıyasla yapının ölçeği de küçülmüştür. Ancak teknolojik donanımı dolayısıyla fonksiyonu aynıdır. Ajitasyon Platformları deneyimlenebilecek bir mekân sunmamakta fakat kentlilere gündelik hayatlarında gelișmiş bir toplum ve kültür ile birlikte yaşadıklarını hatırlatacak niteliktedir.

Konstrüktivist mimarlığın ütopya düzlemindeki gelişiminin teknik açıdan en ileri ve gelişmiş örneklerini Chernikhov'un çalışmalarında görebilmek mümkündür. Chernikhov, Alexander Vesnin gibi diğer avangard sanatçılardan farklı olarak mimarlık formasyonuna sahiptir. Bu bağlam-
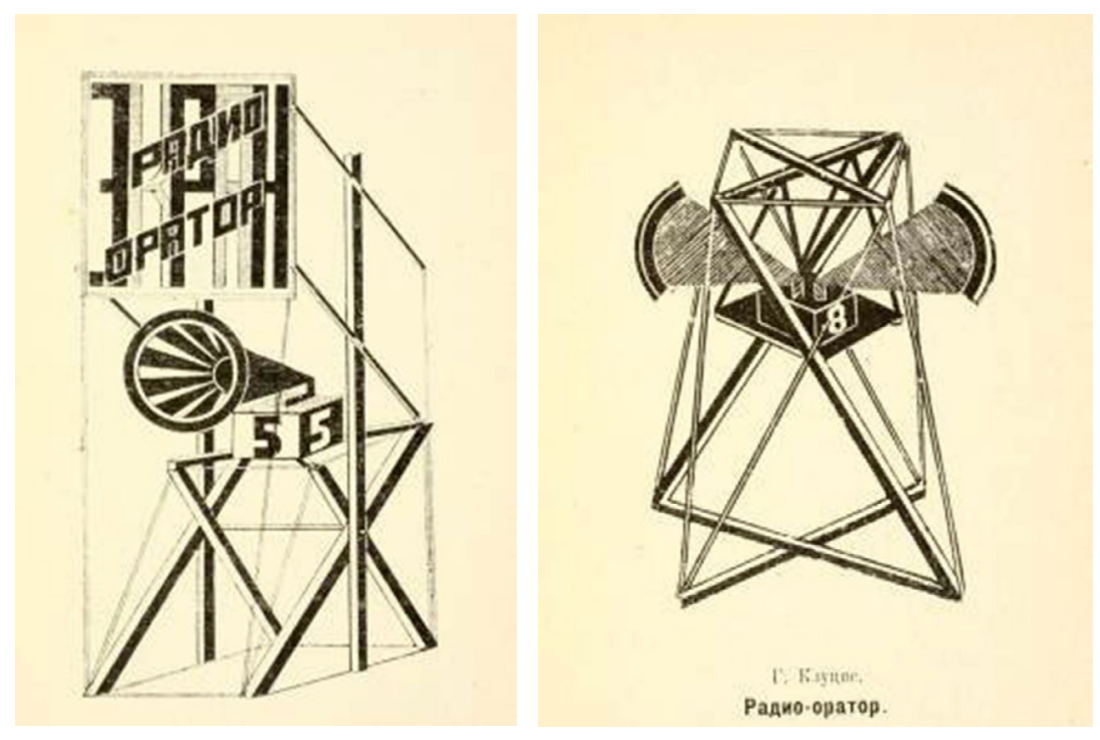

da konstrüktivizmin biçimsel dili ile süprematizmi sentezlerken rasyonalizmi göz önünde bulundurması sadece bir davranış olarak okunamamakta ve yaklaşımının bilimsel temellere dayandığını ifade etmek gerekmektedir. Ayrıca Chernikhov'un 1920-1930 yılları arasında mesleğini icra edebilmesi ve birçok projesinin S.S.

C.B'nin farklı bölgelerinde inşa edilmesi Chernikhov'un ütopya ile gerçeklik arasındaki sınırın farkında olduğunu göstermektedir. 1927-1933 yılları arasında yayınlanan çalışmalarından belki de en ünlü olan, ütopya eksenine kayan ve aynı zamanda inșa edilmesi mümkün olan tasarımların da yer aldığ 1 "101 Architectural Fantasies" çalışması bu savı kanıtlamaktadır.

Chernikhove un tek parça sivil tipte bina olarak adlandırdığı "Kompozsiyon 32", Merkezi Bölge Beden Eğitim Evi olarak tasarladığ “Kompozisyon 33" ve yapısal fabrika sistemleri olarak adlandırdı ̆̆ "Kompozisyon 34" 20. yüzyılın ilk yarısında teknolojinin ve mühendisliğin gelişmesine bağlı olarak inşa edilmesi imkânsız projeler değildir. Buna karşın Rus Konstrüktivizmi'nin fantezisti de olarak bilinen Chernikhov'un tasarımlarını özelleştiren unsur, kendi özerk sistemine sahip olan makineler ve makine parçaları aracılığı ile anıtsal formları aşamalı olarak mimari tasarımlara dönüştürmesidir. "Kompozisyon 83", "Kompozisyon 100" ve "Kompozisyon 101" başta olmak üzere makine ve makine şekil: 5

Ajitasyon Platformları (Margolin, V. (2012). Ütopya Mücadelesi. Istanbul: Espas Kuram Sanat Yayın(ari). 
Şekil: 6

Kompozisyon 100, Kompozisyon 101 (Chernikhov, I. (1933). Arkhitekturnye fantazii. 101 kompozitsiya. Leningrad: Mezhdunarodnaya kniga.
Sekil: 7

Set Tasarımı, Lyobov Popova (Dabrouski, M. (1991). Liubov Popova. Harry N Abrams Inc). șekil: 8

Set Tasarımı, A. Vesnin (Honda, A. (2017). A New Vision in Architecture: Ivan Leonidov's Architectural).

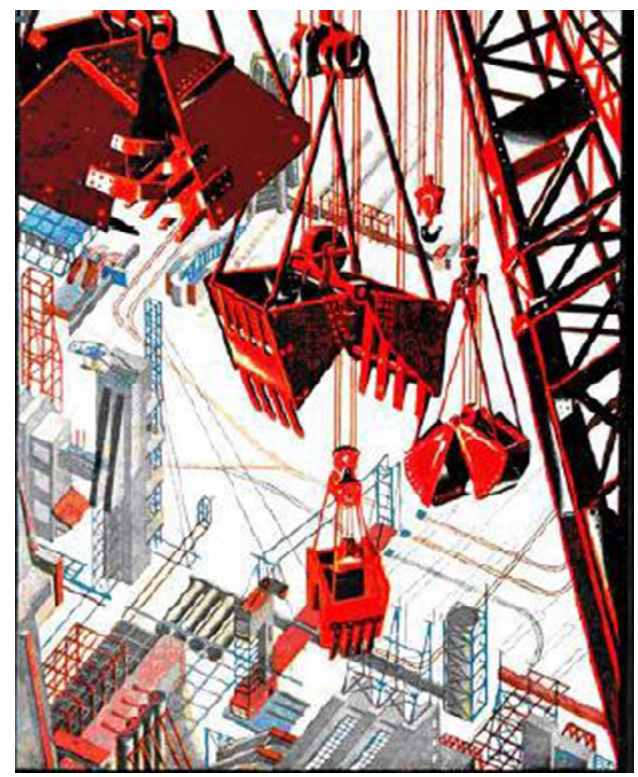

parçalarından yola çıkılarak tasarlanmış mekânlar makine - mimarlık - üretim ilişkisinin gelecekte nasıl olacağını yansıtmıştır. Sanayinin ve teknolojinin geliştiği bir S.S.C.B hayal ederken, makine dünyas1 içinde mekânlar yaratmıştır (Şekil 6).

1920 - 1934 yılları arasında konstrüktivist mimarlık ütopya düzleminde aşamalı olarak gelişmeye devam ederken, ütopya tam olarak gerçekleşmese de hayal edilenin gerçekte nasıl karşılık bulabileceğini gösteren mekânlar tiyatrolarda ortaya çıkmıştır. Ütopya düzleminde konstrüktivist dinamikleri taşıyan öncü sahne tasarımları 1922 yılında Lyobov Popova'nın The Magnanimous Cuckold oyunu, 1923 y1lında Alexander Vesnin'in Bay Perşembe oyunu için tasarladığı sahnelerdir (Sekil 7, 8).

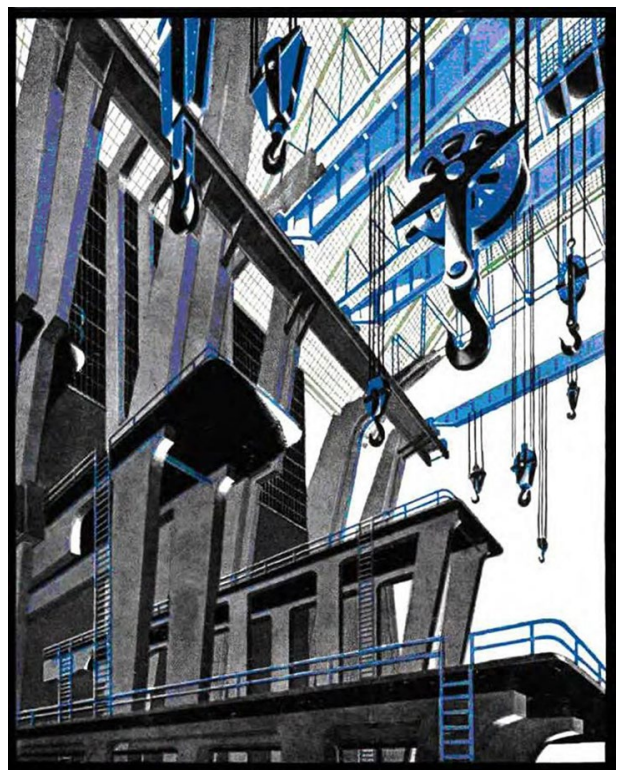

Asansör sistemi, dönen bir vinç, hareketli yürüme yolu, reklam panoları, spot ışıkları olmak üzere teknolojik donanıma sahip olması ön görülen yapı Vesnin tarafından geleceğin tiyatro sahnesi hayal edilerek tasarlanmıştır (Godi, 2015). Reel olarak kullanılan tasarımda ise oyuncuların yapı iskeletinin bağlantı noktalarını kullanarak üst katlara tırmandığı ve oyun esnasında yapının bileşenlerinden üzerinde oturarak, uzanarak, yürüyerek teatral ifadelerinin dışavurumu hususunda faydalandıkları ifade edilmektedir. Popova'nın sahne tasarım 1 ise geleneksel tiyatro sahnesi üzerinde hareket ettiği düşünülen geniş bir disk, iki tane çark, yel değirmeni yelkeni ve platformun üzerine çıkılmasını sağlayan merdivenlerden oluşmaktadır. Her iki sah-
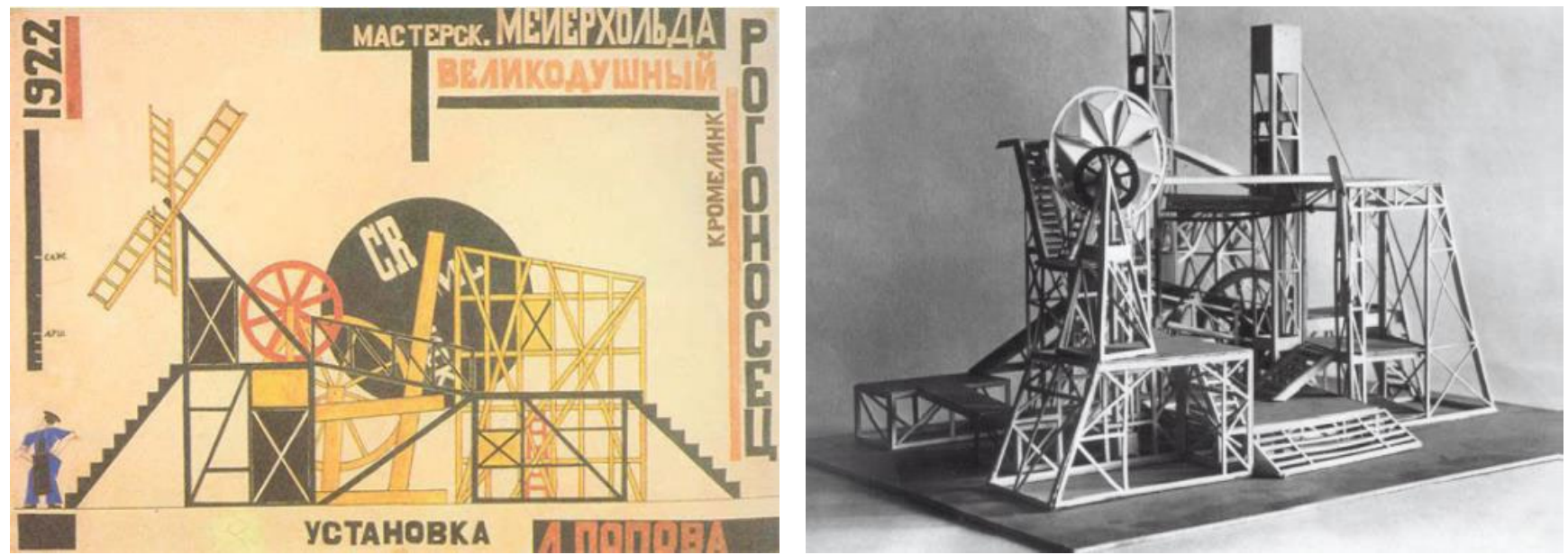
ne de teknolojik donanımı olmaksızın inşa edilmiş ve oyunlarda kullanılmıştır.

Konstrüktivistlerin sahne tasarımları ile ütopyaların gerçekleşip gerçekleşmediği sorusunun cevabı hem evet hem hayırdır. Tektonik - faktura - konstrüksiyon ilişkisi, malzemelerin organizasyonu, kullanılan endüstriyel malzemeler ve uzamsal bağlantılar referans alındığında konstrüktivistlerin hayallerinin tiyatrolarda hayat bulduğunu söylemek mümkündür. Teknolojik sistemlerin ve makinelerin sahne tasarımlarında yer almadığı göz önünde bulundurulduğunda ise tasarımların model olmanın ötesine geçemediği ve konstrüktivistlerin ütopyasının gerçekleşmediği düşünülebilir. Bu bağlamda tasarımlar ütopya düzleminde kalmış, tasarımların inşa edilen modelleri ise hayal edilen nitelikleri olmaksızın inşa edilmiştir.

Ütopya düzleminde konstrüktivist mimarlığın gelişimi göz önünde bulundurulduğunda konstrüktivist tasarımların sadece S.S.C.B'nin ekonomik imkanlarının yetersizliği ve çă̆ının ötesinde tasarımlar olmaları nedeniyle inşa edilemediği analizi yetersiz kalmaktadır. Tasarımların S.S.C.B halkının ihtiyaçlarının, dönemin nesnel koşullarının referans alınarak tasarlanmaması nedeniyle inşa edilemediğinin ve konstrüktivistlerin teorileri ile pratiklerinin çeliştiğini vurgulamak gerekmektedir. Konstrüktivist mimarlığın ütopya düzleminde değerlendirilen örneklerini tasarlayan sanatçı ve mimarlar sosyalist düzenin inşa sürecindeki temel gereksinimleri ve ihtiyaçları ile ideal tasarım arasındaki ikilemde ideal olanı tercih etmişler, teorilerini sadece söylem olarak sosyalist ideolojiye içkin bir hale getirmeleri nedeniyle pratikleri hayat bulmamıştır. Buna karşın III. Enternasyonal Anıtı'nda mimari yapının sahip olduğu teknolojik donanım ile sosyalizmin propagandasını yapan canlı bir organizmaya dönüşmesi, makinenin yapısı ile mimari tasarım arasında kurulan ilişki, tektonik, faktura ve konstrüksiyon disiplinleri ile geliştirilen yaklaşım devrim mimarlı̆̆ının inşasında görev alan konstrüktivistlerin sosyalist düzeni yansıtan yapıların ve mekânların tasarlamasında etkili olmuştur.

\section{Ütopya Düzleminden Reel Düzleme Geçiş}

Konstrüktivist mimarlığın S.S.C.B'de devrim mimarlığının inşası için bir seçeneğe dönüşme süreci 1923 yılında Moskova Mimarlar Topluluğu'nun Emek Sarayı için düzenlediği mimarlık yarışmasıyla başlamıştır. Alexander Vesnin ile kardeşleri Viktor ve Leonid Vesnin'in Emek Saray tasarımı sunulan 46 proje arasında bütün ilgiyi üzerine toplamıştır (Şekil 9). Moskova'da kent imgesini oluşturacak olan saray fabrika biçiminde tasarlanmış; üretim, işçi sınıfı ve sosyalist düzenin mimari kimliğinin vurgusu analoji ile yapılmıştır. Tasarımın gövdesini dikdörtgen prizma ve üst üste bindirilmiş silindir biçimindeki iki betonarme blok oluşturmakta ve bağlantı elemanları ile bloklar arasında geçiş sağlanmaktadır (Honda, 2017).

Projede sosyalist propagandanın analoji ile yapılarak soyut düzlemde kalması, endüstriyel malzemelerin ve teknolojik donanımın vurgulanması ütopya mimarlığ 1 kapsamında değerlendirilen konstrüktivist tasarımların yansıması olarak kabul edilebilir. Ancak Emek Sarayı'nda endüstriyel malzemelerin form - fonksiyon ilişkisine bağlı kalınarak seçilmesi, çağının ötesinde teknolojik donanıma sahip olmaması ve nesnel koşulların referans alınarak tasarlanması söz konusu projeyi ütopya mimarlığ kapsamında değerlendirilen tasarımlardan ayırmakta ve Emek Sarayı tektonik, faktura ve konstrüksiyon bileşenlerinin reel düzlemde de uygulanabileceğini kanıtlayan ilk tasarım olma özelliğini taşımaktadır.

Emek Sarayı aynı zamanda Alexander Vesnin'in geleneksel ve eklektik yaklaşımı benimseyen mimarlar karşısında geliştirdiğ $i$ ilk projelerden birisi olarak kabul edilmektedir (Epstein-Pliouchtch, 2002). Konstrüktivist mimarlığın teorisyeni Moisei Ginzburg'un Emek Sarayına "konstrüktivizmin ilk somut mimari eylemi" ifadesiyle atıfta bulunması, tasarımın konstrüktivist mimarlığın gelişimi açısından önemini kanıtlar niteliktedir (Cooke, 1990, s. 23). Vesnin Kardeşlerin Emek Sarayı projesinde geliştirdikleri yaklaşımın benzeri ise ikinci büyük projeleri olan Pravda Gazetesi Binası'nda da görülebilir (Şekil 10). Yap1 teknolojik donanıma sahiptir 


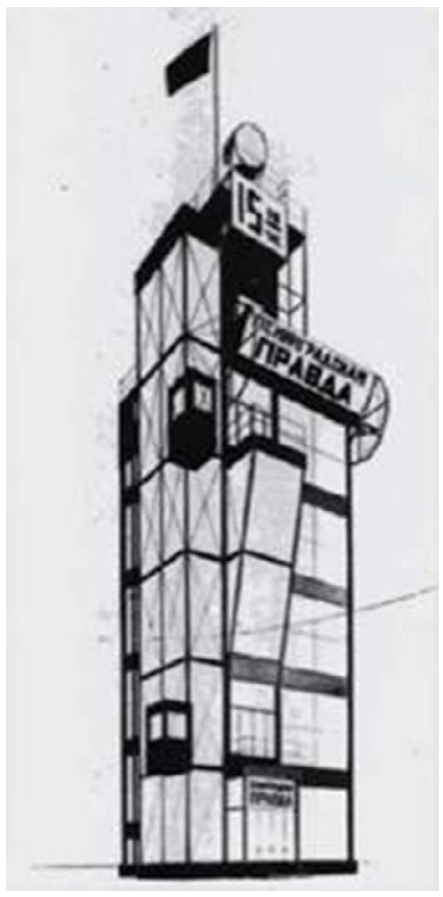

Şekil: 9

Emek Sarayı (Honda, A. (2017). A New Vision in Architecture: Ivan Leonidov's Architectural Projects Between $1927-1930$. Waseda University Press, 79-94).

Sekil: 10

Pravda Gazete Binasi (Honda, A. (2017). A New Vision in Architecture: Ivan Leonidov's Architectural Projects Between $1927-1930$. Waseda University Press, 79-94).

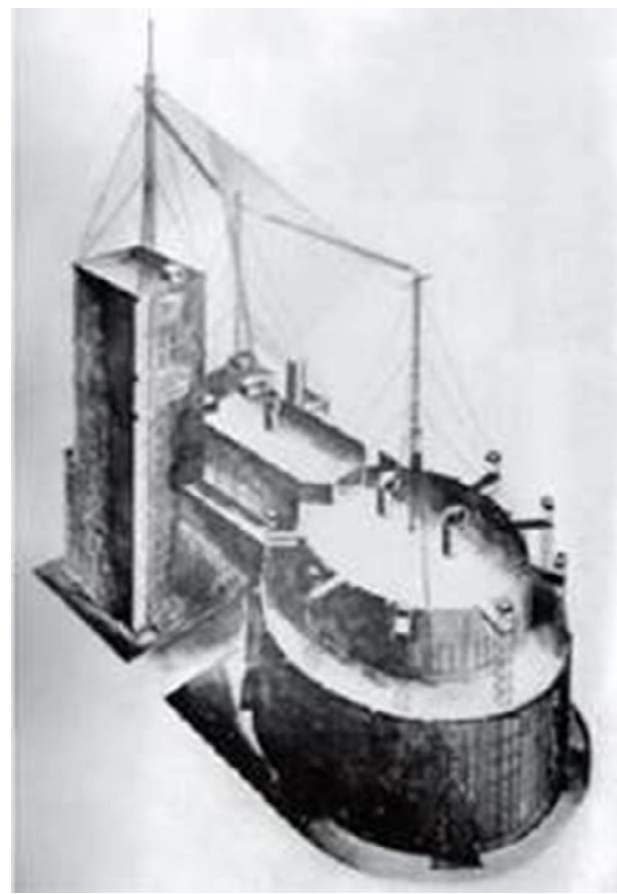

ancak çağının ötesinde bir tasarım değildir. Sovyet mimarisi için yenilik olarak kabul edilen unsur camın kullanım biçimidir. Çelik iskelete sahip yapı cam perde duvarlarla binanın etrafindan yürüyen yayaların gerekli haberlere ve bilgilere vâkıf olmasını ve gazetenin basılma sürecini takip etmesini sağlamaktadır. Emek Sarayı ve Pravda Gazetesi Binası inşa edilmemesine karşın; Vesnin Kardeşlerin ilk büyük projeleri olarak dikkat çekmiş, Sovyet mimarisinin gelişmesinde reel düzlemde mihenk taşı görevi görmüş, konstrüktivist mimarlığı sosyalist düzene ait özgün yapıların inşası için bir seçenek haline getirmiştir.

Emek Sarayı için düzenlenen mimarlık yarışması ile aynı yıl düzenlenen Rus Tarım ve El Sanatları Sergisi de eklektisist yaklaşıma karşı modernist yaklaşımı benimseyen mimarlara birbirlerinin projelerini gözlemleme şansı sunmuştur (Cooke, 1990). S.S.C.B'nin kuruluşunun ilk yılı olması dolayısıyla mimarlar kırsal nüfusun ihtiyaçlarını karşılamak amacıyla farklı işlevlere sahip pavilyonlar tasarlamışlar, Melnikov'un köylülerin tütün depolaması için tasarladığ 1 Makhorka Pavilyonu ve Moisei Ginzburg'un Kirım Pavilyonu burada sergilenmiştir (Anderson, 2015). Bu dönemde kilit rol oynayan gelişme ise konstrüktivist mimarlığın yapı taşı olarak kabul edilen, Ginzburg'un kaleme aldığ 1 Style and Epoch (Stil ve Çă̆) çalışmasının 1924 yılında yayınlanmasıdır.

Style and Epoch çalışması modern mimarlığın incelenmesinin aciliyeti vurgulanarak başlamakta, eklektisizm mahkum edilerek sanatçı, mimar ve mühendisin üretim metotları arasındaki ilişkiye değinilerek oluşmakta olan yeni mimari dilin önüne geçilemeyeceği ifade edilmektedir (Ginzburg, 1982). Bununla birlikte gelişen mimarlık teorisi ve teknoloji, tektonik tarz, faktura ve konstrüksiyon disiplinleri, makinenin yapısı, mimaride konstrüksiyon ve formu oluşturan nitelikler, makinenin modern sanata olan etkisi irdelenmektedir. Ginzburg'un teorisini Alexei Gan ve Tatlin'nin teorisinden ayıran faktörler tektonik, faktura ve konstrüksiyonun yeni bir mimari üslubu oluşturan ana unsurlar değil vazgeçilmez bir parçası olarak tanımlanması gerektiği ve makinenin ele alınış biçimidir. Ginzburg makinenin doğrudan kendisini değil makineyi oluşturan her parçanın dekoratif elementler kullanılmaksızın amaca yönelik olarak tasarlanması ve bir bütünü oluşturması dolayısıyla mimarlıkla ilişkilendirmekte ve konstrüktivist mimarlığın teorisini yeniden ele alarak reel bir düzleme oturtmaktadır.

\section{Reel Düzlemde Konstrüktivist Mimarlık}

Vesnin Kardeşlerin tasarımları ve Ginzburg'un Style and Epoch çalışması konstrüktivist mimarlığı pratikte uygulanabilir bir zemine taşımıştır. Ancak eklektisist yaklaşıma karşı modernist yaklaşımı benimseyen mimarlar tek bir cephede örgütlenmemiş, Vkhutemas'ta ders veren, konstrüktivistlerin teorilerine karşı çıkan ve kendilerini rasyonalist olarak adlandıran Nikolay Ladovsky ve Vladimir Krinsky 1923 yılında ASNOVA ${ }^{8}$ 'yı kurmuşlardır. Buna karşın konstrüktivistlerin fikirlerini benimseyen Vkhutemas'ta mimarlık eğitimi alan öğrenciler merkezi bir figür olan Alexander Vesnin'in etrafinda toplanmış ve bu taraflaşma 1925 yılında konstrüktivist mimarların örgütlendiği OSA'nın kurulmasıyla sonuçlanmıştır (Cooke, 1990). 1926 yılında OSA9'nın yayın organı olan Sovre- 

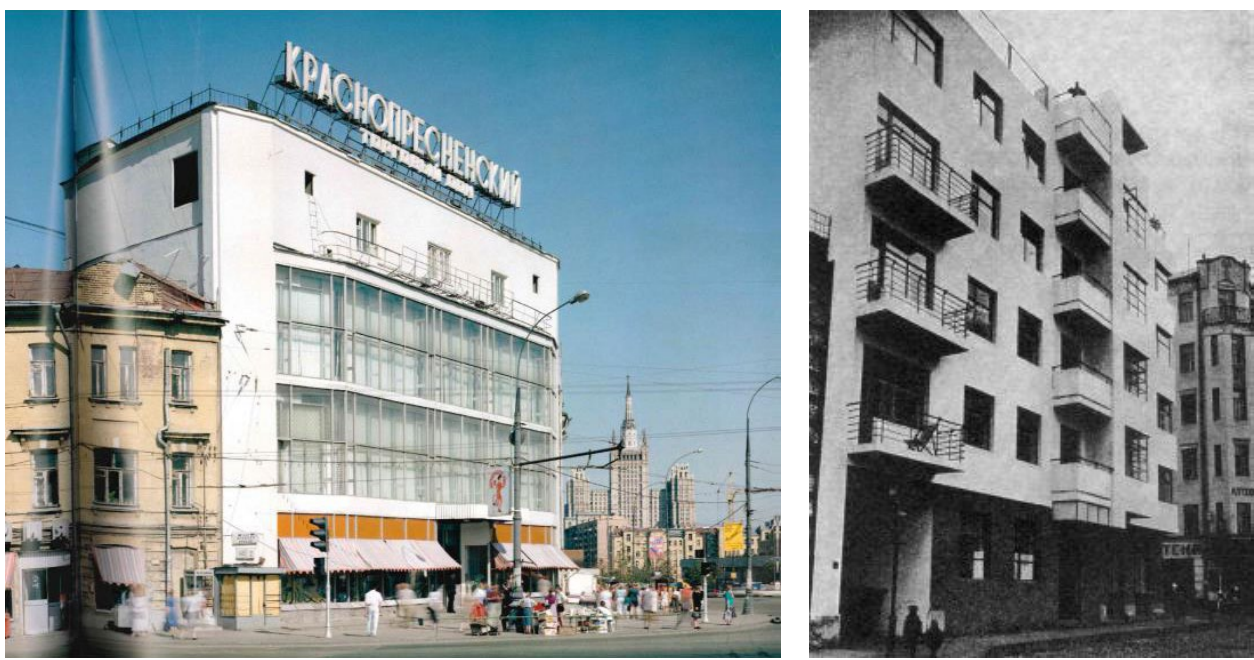

mennaya Arkhitektura'nın yayınlanmasıyla konstrüktivist mimarlık S.S.C.B'ye tan1tılmış ve 1927 yılında OSA mimarlarının Mostorg Alıșveriş Merkezi ve Gosstrakh Apartmanı olmak üzere ilk konstrüktivist projeleri inşa edilmiştir (Şekil 11, 12).

Vesnin Kardeşler tarafından tasarlanan ve konstrüktivist karakteri yansitan Mostorg Alışveriş Merkezi Moskova'nın Petrovka Caddesi'nde yer almaktadır. Konumlandığı köşe dolayısıyla iki cephesindeki komşu yapılar tarafından sınırlandırılmış, sokağa bakan iki cam cephe ise yoldan geçen insanların alışveriş merkezinde gerçekleşen ticaret ve değiş tokuş eylemini engelsiz bir görüş açısıyla takip etmesine olanak vermiştir (Pare, 2007). Bu bağlamda Vesnin Kardeşler'in Pravda Gazetesi tasarımında halka sağlamaya çalıştığı şeffaf görüş açısı Mostorg Alışveriş Merkezi pratiğinde karşılık bulmuş, cam kapitalist düzenden farklı olarak tüketimi teșvik etmek için değil halk arasındaki güven ilişkisinin tahsis edilmesi amaciyla kullanılmıştır. Çalışma eyleminin ve kültürünün kent nüfusu tarafindan deneyimlenmesi, bu kültürün konstrüktivist yapılar aracılığ ile kent insanına propagandasının dolaylı yoldan yapılması, üretimin ve ticaretin kapalı kapılar ve mat duvarlar ardında gerçekleşmemesi mimarlık açısından bir yeniliktir. Farklı bir biçimde ifade etmek gerekirse Mostorg Alışveriş Merkezi tüketim kültürünün değil sosyalist düzenin bir ürünüdür.
Gosstrakh Devlet Sigorta Kurumu çalışanları için Ginzburg'un inşa ettiği köşe parselde konumlanan beş katlı konut yapısının ise konstrüktivist mimarlığın özgün örneklerine kıyasla öne çıkan bir yapı olmadığını ifade etmek gerekmektedir. Ancak OSA mimarlarının 1920'li yılların sonunda tanımladıkları ve mekân organizasyonunda ana belirleyen olan sosyal yoğunlaştırıcı kavramının pratikte uygulandığı ilk konut yapısı olması dolayısıyla Gosstrakh Apartmanı konstrüktivist mimarlığın gelişimi açısından önem taşımaktadır (Urban, 2012). Sosyal yoğunlaştırıcı kavramının temelinde yatan düşünce, sınıf farkının ortadan kalktığı, hiyerarşinin olmadığ $\breve{1}$ bir dünyada kolektif yaşamın örgütlenmesi, proletarya kültürünün ve sosyalist düzenin kazanımlarının mimarlık aracılığıyla topluma taşınmasıdır. Bu bağlamda Gosstrakh Apartmanı'nda şehrin manzarasının izlenmesine olanak veren ortak teras, konut yapısında mekânlar aracılığıyla sağlanmaya çalışılan kolektif yaşam kurgusunun başlangı̧̣ noktasını oluşturmaktadır.

Sosyal yoğunlaştırıcı kavramının doğrudan karşlık bulduğu ilk örnekler 1925 - 1927 yılları arasında işçiler için inşa edilmesi hedeflenen yapılar için düzenlenen mimarlık yarışmalarında; uygun mimari ifadenin bulunması, hijyen koşullarının, konforun, estetiğin ve mekân organizasyonu ile kolektif yaşamın kurgulanmasının şart koşulmasının sonucunda ortaya çıkan işçi kulüpleridir (Bokov, 2017). İşçi kulüpleri ideolojik eğitimlerin, toplantıların, kültür
Şekil: II

Mostorg Alışueriş Merkezi (Pare, $R$.

(2007). Verlorene Avantgarde: Russische Revolutionsarchitektur 1922-1932. München: schirmer und Mosel Verlag).

şekil: 12

Gosstrakh Apartmanı (Vesnin, A., \& Ginzburg, M. (1927). Souremennaya Arkhitektura). 


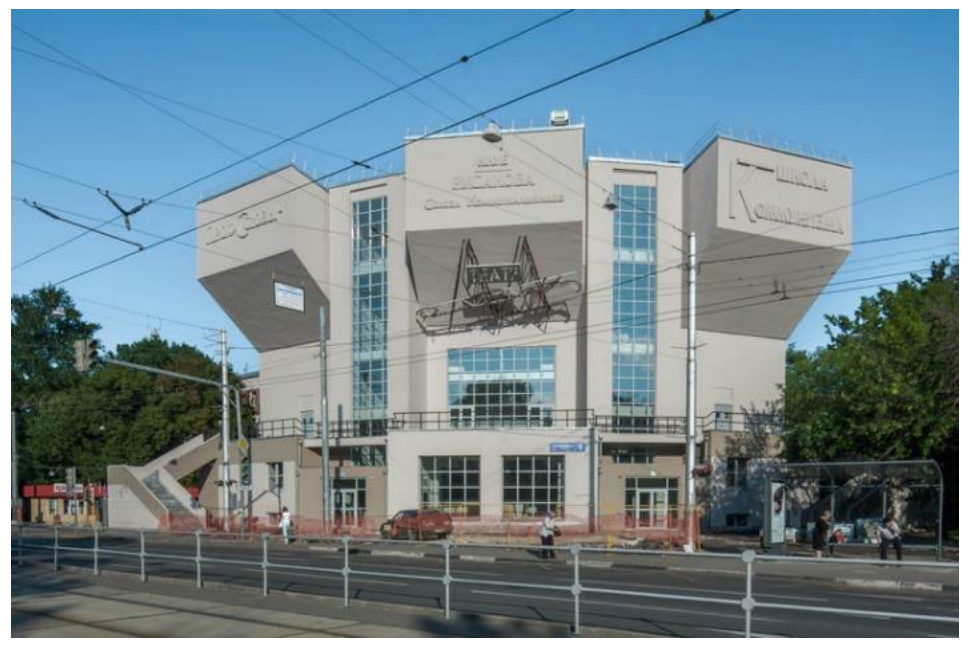

Şekil: 13

Rusakov iş̧̧i Kulübü (Pare, R. (2007). Verlorene Avantgarde: Russische Revolutionsarchitektur 1922-1932. München: schirmer und Mose( Verlag).

şekil: 14

Zuev Iş̧i Kulübü (Pare, R. (2007). Verlorene Avantgarde: Russische Revolutionsarchitektur 1922-1932. München: schirmer und Mosel Verlag).

Şekil: is

Surahanı Iş̧̧i Kulübü (Pare, R. (2007). Verlorene Avantgarde: Russische Revolutionsarchitektur 1922-1932. München: schirmer und Mosel Verlag).

Konstantin Melnikov'un tasarladığ 1 sanat aktivitelerinin, kitlesel etkinliklerin yapıldı ğ 1 , işçilerin mesailerini tamamlamalarının ardından niteliklerini geliştirebilecekleri, sosyalleşebilecekleri mekânlar olarak tanımlanabilir. Rusakov İşçi Kulübü ilk inşa edilen işçi kulüplerinden biri olarak sonrasında inşa edilen işçi kulüplerine model oluşturması ve konstrüktivist mimarlığın kimliğini yansıtması dolayısıyla önemli bir örnektir (Şekil 13). 1927 yılında inşası tamamlanan dinamik, basit geometrik formların kompozisyonundan oluşan yapı, üçgen bir zemin üzerinde yelpaze şeklinde açılarak yükselen üç ana bloktan oluşur. Yapının dışına taşan bloklar kolonlarla desteklenirken cephede yer alan merdivenler aynı zamanda yangın merdiveni olarak kullanılır. Yapının arka avlusunun duvarlarında tuğla kullanılarak işçi kulübünde düzenlenen etkinlikler dışında da vakit geçirmek isteyen insanların bir araya gelebileceği samimi bir ortam yaratılmış, her mekânı bölen hareketli duvarlar aracılığıyla söz konusu yapı farklı kapasitelere sahip toplanma alanlarına dönüştürülebilir hale getirilmiştir (Palmer, 2016). Diğer ikonik yapı ise Ilya Golosov'un tasarladığı Zuev İşçi Kulübü'dür (Sekil 14). Günümüzde tiyatro salonu ve kültür merkezi olarak kullanılan yapıda mekânsal ve formal olarak yaratılmaya çalışılan kamusal alanla bütünleşme hissi, şeffaf yüzeyler ve cam silindir şeklinde tasarlanan dolaşım hacminin dışa doğru çıartılmasıyla sağlanmıştır. Zuev

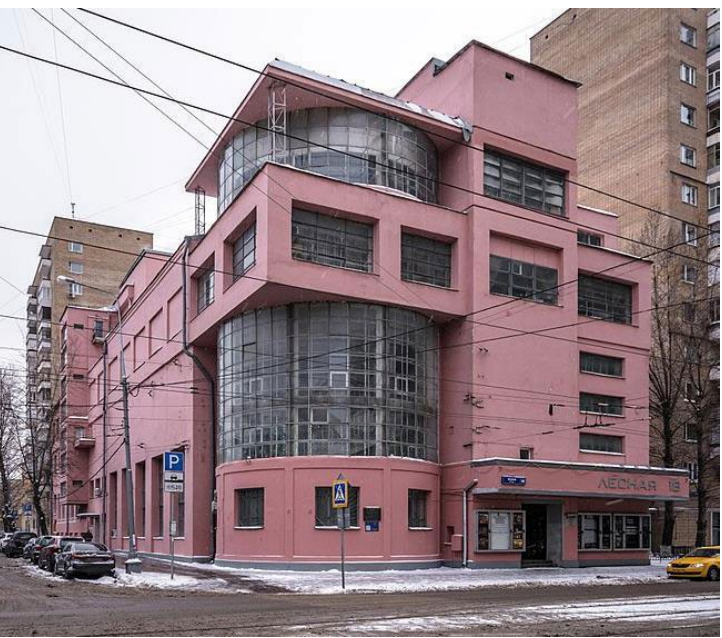

İşçi Kulübü ile Rusakov İşçi Kulübü’nün tasarımı arasındaki benzerlik; tasarım yaklaşımı, kullanılan malzemeler, dinamik forma sahip olması dolayısıyla kolaylıkla kurulabilmekte, günümüzde işçi kulübü tasarımları arasında en karakteristik iki örnek olarak tanımlanmaktadır.

1927 - 1934 yılları arasında işçi kulüpleri sadece Moskova'da değil S.S.C.B'nin farklı bölgelerinde ihtiyaca yönelik olarak inşa edilmiştir. Ancak inşa edilen işçi kulüplerinin yapısal niteliklerinin ve mekân organizasyonunun tek tip olduğunu söylemek olanaksızdır. Tasarım dili Melnikov ve Golosov'dan farklı olan, 1929 yılında Vesnin Kardeşler tarafından Bakü'de inşa edilen Surahanı İşçi Kulübü örnek olarak gösterilebilir (Şekil 15). Ana blok ve iki tiyatro sahnesinden oluşan yapı günümüzde ayakta olmasına karşın korunmaması

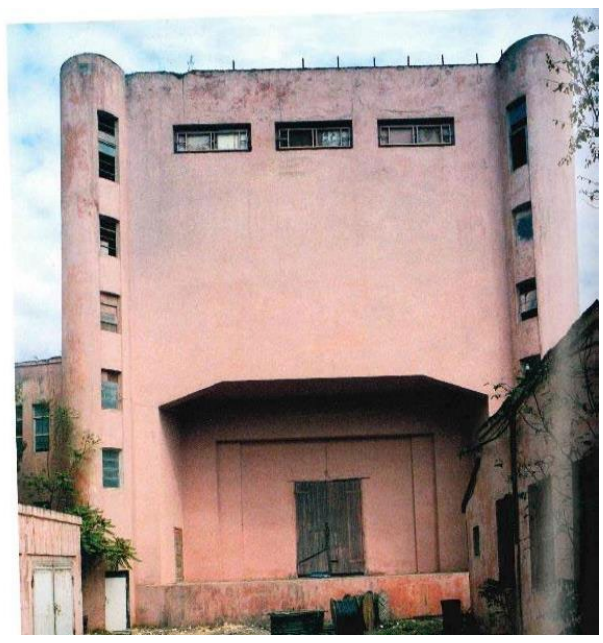




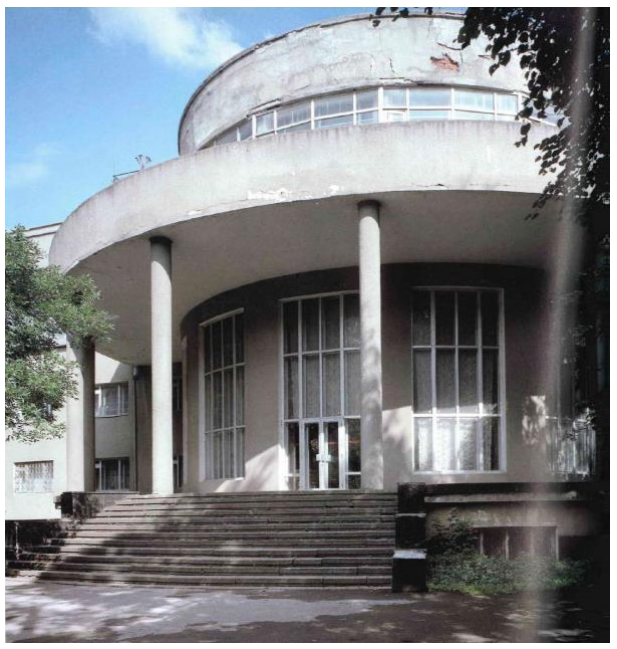

nedeniyle yıpranmış ve işlevini kaybetmiştir (Pare, 2007). Yapının içinde iki tiyatro sahnesinin bulunması konstrüktivist yapılar aracılığıyla kurgulanan hayatı ve sosyalist kültürü yansıtmaktadır.

Vesnin Kardeşlerin sosyal yoğunlaştırıcı kavramını esas alarak gerçekleştirdikleri proje ise Moskova'nın Proletarsky ilçesinde ağır araç üreten ZİL Fabrikası'nda çalışan işçiler için tasarladıkları ZIL Kültür Sarayı'dır (Şekil 16). Kültür sarayları işçi kulüplerinin fiziksel ve fonksiyonel olarak genişletilmiş sosyal formlarıdır. 1000 kişilik ve 4000 kişilik oturma yerine sahip iki tiyatro salonu, kütüphane, 250 kişilik bir oditoryum, laboratuvarlar, restoran, kafe ve çalışma alanlarına sahip olan ZIL Kültür Sarayı'nda sanatsal ifade ve fonksiyonel gereksinimler doğrultusunda bir araya getirilen mekânlar ustaca tasarlanmış bir modülasyon etkisi uyandıracak biçimde kurgulanmıştır. Yapının cephesi sade ve basit olup, fonksiyonel çeşitlilik yoğun olmasına rağmen iç mekân organizasyonu gürültülü ve sessiz bölgelerin uygun yerleşimi göz önünde bulundurularak tasarlanmıştır.

Konstrüktivist mimar Alexander Gegello ve David Krichevsky tarafindan St. Petersburg'un merkezine inşa edilen, 1900 kişilik tiyatro salonuna sahip olan Gorki Kültür Sarayı da benzer bir ihtiyacın ürünüdür (Şekil 17). Dolayısıyla iş̧̧i kulüplerinin ve işçi kulübünün mimari hacmi ile fonksiyonunun genişletilmiş biçimi olan kültür saraylarının tasarımı, mekân organizasyonu ve mimarlık dili hususunda belirli bir standardizasyonun olmadığı ve konstrüktivist ilkeler ile sosyalist yaşam biçiminin tasarımları şekillendirdiğini vurgulamak gerekmektedir.

Aynı yaklaşım 1928 yılında kurulan STROIKOM ${ }^{10}$ 'un standart ev tiplerini tasarlaması amaciyla görevlendirilen Moisei Ginzburg'un prototip olarak tasarladığ 1 Narkomfin Evi'nde görülebilmektedir (Buchli, 1998). Yatay düzlemde uzanan, 54 birime sahip, pilotiler üzerinde yükselen konut yapısı ve komünal blok olmak üzere iki ana bloktan oluşan Narkomfin Evi'nin fiziksel özellikleri modern mimarlığın al1şılagelmiş örneklerini andırmaktadır (SSekil 18). Ancak Narkomfin Evi'ni konstrüktivist mimarlık kapsamında ayrıştıran unsur sosyal yoğunlaştırıcı kavramının konut yapısında uygulanması dolayısıyla radikal bir örnek oluşturması, mimarlık tarihi kapsa-

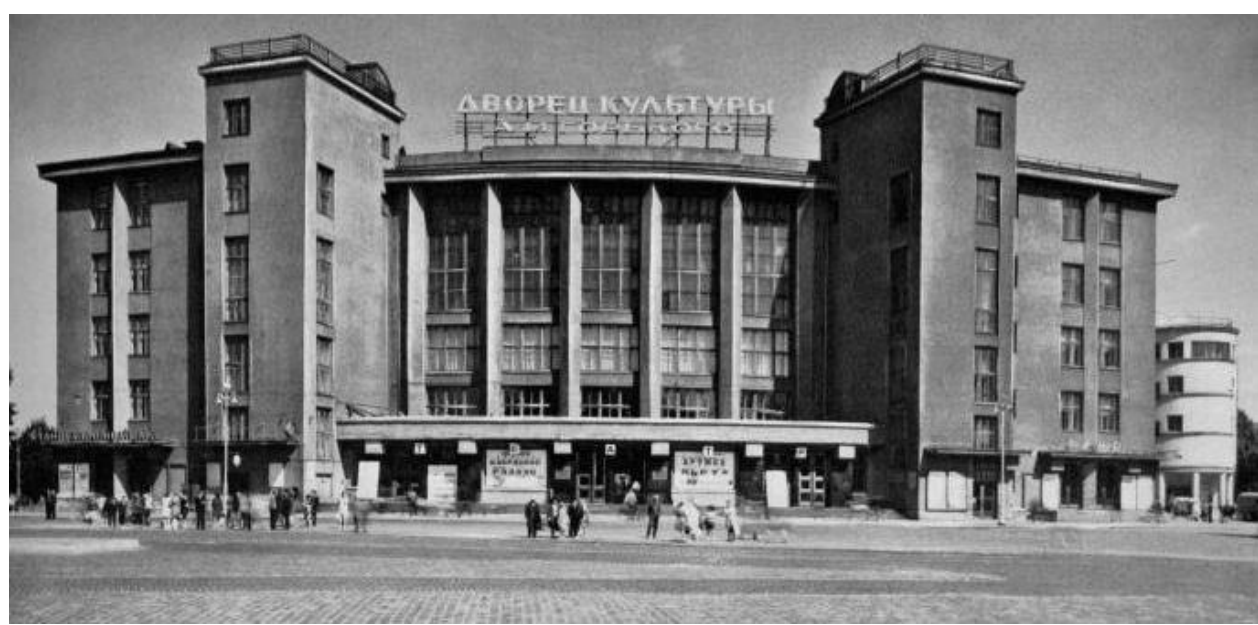

Şekil: 16

ZIL Kültür Sarayı (Pare, R. (2007). Verlorene Avantgarde: Russische Revolutionsarchitektur 1922-1932. München: schirmer und Mosel Verlag).
Sekil: 17

Gorki Kültür Sarayı (Pare, R. (2007). Verlorene Avantgarde: Russische Revolutionsarchitektur 1922-1932. München: schirmer und Mosel Verlag). 


\section{Şekil: 18}

Narkomfin Evi (Pare, R. (2007). Verlorene Avantgarde: Russische Revolutionsarchitektur 1922-1932. München: schirmer und Mose( Verlag).

şekil: 19

F Birimi (Pare, R. (2007).

Verlorene Avantgarde: Russische Revolutionsarchitektur 1922-1932. München: schirmer und Mosel Verlag).
Şekil: 20

Melnikov Evi (Pare, R. (2007).

Verlorene Avantgarde: Russische

Revolutionsarchitektur 1922-1932. München: schirmer und Mosel Verlag).

şekil: 2 I

Melnikov Evi Giriş (Pare, R. (2007). Verlorene Avantgarde: Russische

Revolutionsarchitektur 1922-1932. München: schirmer und Mosel Verlag).
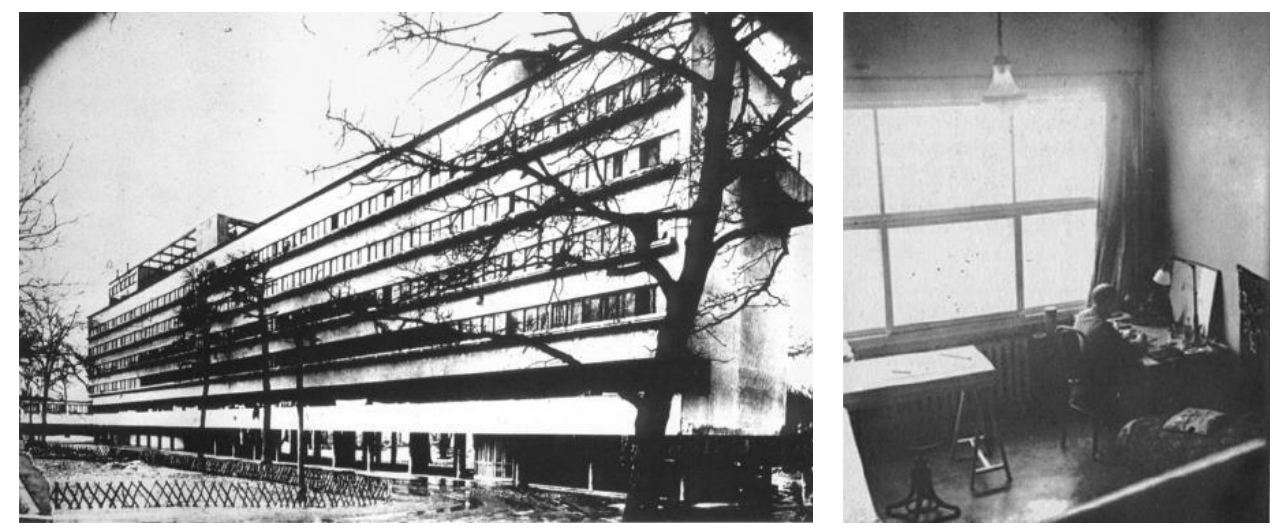

mında ayıran unsur ise mekân organizasyonu aracılığı ile kolektif yaşamın örgütlenmesidir. Beş katlı konut yapısında yalnız, çift olarak yaşayan ve çocuklu aileler için farklı tipte yatak odalarının bulunduğu B, $\mathrm{C}$, D birimleri tasarlanmış, F birimi çekirdek ailenin geleneksel tipte vakit geçirebileceği bir alan olarak kurgulanmıştır (Şekil 19). Söz konusu birimler dolaşımın kolay sağlanabilmesi için merdiven boşluğuyla başlayan ve biten koridorlara bağlanmıştır.

Beş katlı konut yapısı ile camekân olan komünal blok dışarıdan görülebilen bir köprü ile birleştirilmiş, içerisinde kütüphane, spor salonu, yemek odası ve mutfağ $ı$ barındıran komünal blok insanların sosyalleşmesi için tasarlanmıştır (Mikadze, 2012). Diğer yandan konut yapısında geniş koridorlar kullanılarak insanların etkinlik yapmadıkları süreçte dahi sosyalleşmelerinin sağlanması amaçlanmıştır. Kolektif yaşam Narkomfin Evi'nde mekân organizasyonu aracılığı ile kurgulanırken kolektifi oluşturan bireylerin yaşam alanlarına saygı duyulmuş ve her

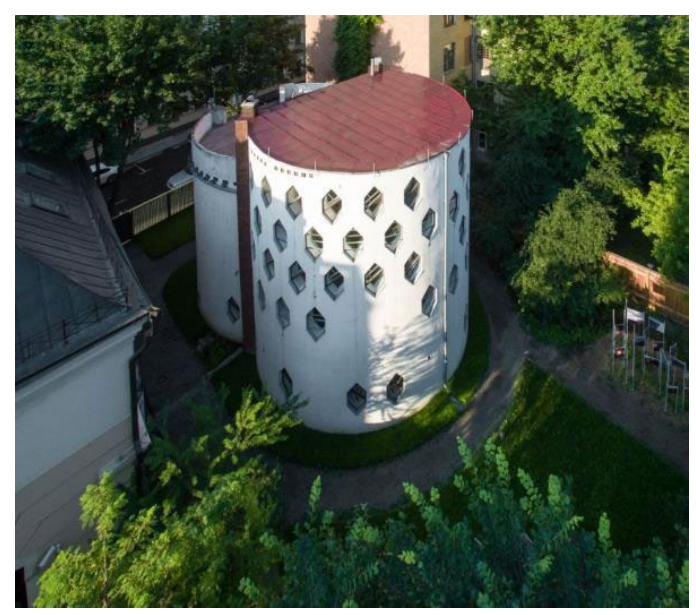

birim ihtiyaçlar gözetilerek tasarlanmıştır.

Konstrüktivist mimarlığı oluşturan bileşenler, sosyalist düzenin dinamikleri ve sosyal yoğunlaştırıcı kavramı esas alınarak inşa edilen işçi kulüpleri, kültür sarayları, komün evi ve apartmanların yanı sıra istisnai bir örnek olan Konstantin Melnikov'un evinden söz etmek gerekmektedir (SSekil 20, 21). Sovyet modernizminin yükseldiği dönemde herhangi bir mimarın kendi evini inşa ettiğine dair bir veri bulunmamaktadır. Ancak Konstantin Melnikov'un prototip yaratma ihtimali Moskova'daki yetkililerin ilgisini çekmiş ve yaşayacağı konut yapısını inşa etmek için gerekli izinleri alabilmiştir.

Birbirine eklemlenmiş silindirlerden oluşan yapının ana malzemesi beton değil ağırlığa dayanıklı bir tuğladır. Yapının duvarlarında sadece alçı ve sıva kullanılarak diagrid bir sisteme dönüştürülmüş buna bağlı olarak herhangi bir destek elemanı kullanılmamıştır. Caddeye bakan silindirin zemin katı hol, yemek odası ve mutfak; altıgen

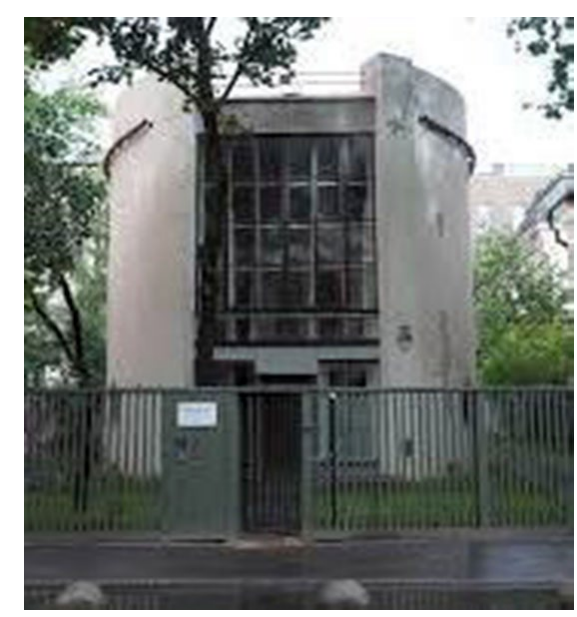


pencerelere sahip silindirin zemin katında ise tuvalet, dinlenme odası ve kiyafet odası yer almaktadır. Sokağa bakan silindirin birinci katı salon olarak işlevlendirilmiş ve geniş pencereler kullanılarak aydınlatma sağlanmıștır. Altıgen pencerelere sahip silindirin birinci katında yatak odası ve ikinci katında terasa erişimin sağlandığı stüdyo bulunmaktadır (Davies, 2006). Bu bağlamda vurgulanması gereken ilk husus Melnikov'un kendisinin yaşayacağı ve işçi sınıfı için prototip olarak inşa ettiği konut yapısını kolektifi oluşturan bireyin ihtiyaçlarını göz önünde bulundurarak tasarlamasıdır. Sosyalist düzenin yaratmak istediği yeni insanın ihtiyaçlarını hem bireysel hem de aile yaşantısı içinde karşılayabileceği stüdyo, dinlenme odası, teras gibi ortak alanlar yaratması bunu kanitlar niteliktedir. Vurgulanması gereken ikinci husus ise Melnikov Evi'nin nitelikleri ile inşa edilen konstrükvist yapılar kıyaslandığında tasarım dilleri arasında ilişki kurulamayacağına dair görüşlerin mevcut olmasıdır. Bu noktada ütopya düzleminde değerlendirilen tasarımlara geri dönmek gerekmektedir. Tatlin, Rodchenko ve diğer konstrüktivistlerin tasarımları göz önünde bulundurulduğunda Melnikov da geleceğin ideal konut yapısını hayal ederek ve sosyalist düzende yaşayan bir işçiyi referans alarak tasarımını şekillendirmiştir. Altıgen pencereleri ile delinmiş silindir görünümüne sahip, dişar1dan bakıldığında bir platenaryumu andıran Melnikov Evi, konstrüktivistlerin ütopya düzleminde değerlendirilen tasarımları gibi bulunduğu zamanın gerçekliğinin oldukça dışındadır. 1936 yılında inşası tamamlanan Melnikov'un tasarladığg Gosplan Garajı da bu sav1 destekler niteliktedir (Sekil 22). Garajın yanında idari birim olarak işlevlendirilmiş dört katlı bir binanın batı cephesinde yarım sütunlarla kesilmiş izlenimini veren yivli bir yüzey yer almakta, pencereler avluya bakmaktadır. Araba garajı kompleksinin ana bölümünü ise içinde kafetarya bulunan ve cephesinde göz biçiminde pencereye sahip olan blok oluşturmaktadır. Yapı göz aracıllı̆ıyla garaja gelen insanları adeta izlemekte ve karşılamaktadır. Melnikov Evi gibi Gosplan Garajı da tasarımı dolayısıyla içinde bulunan zaman dilimi-

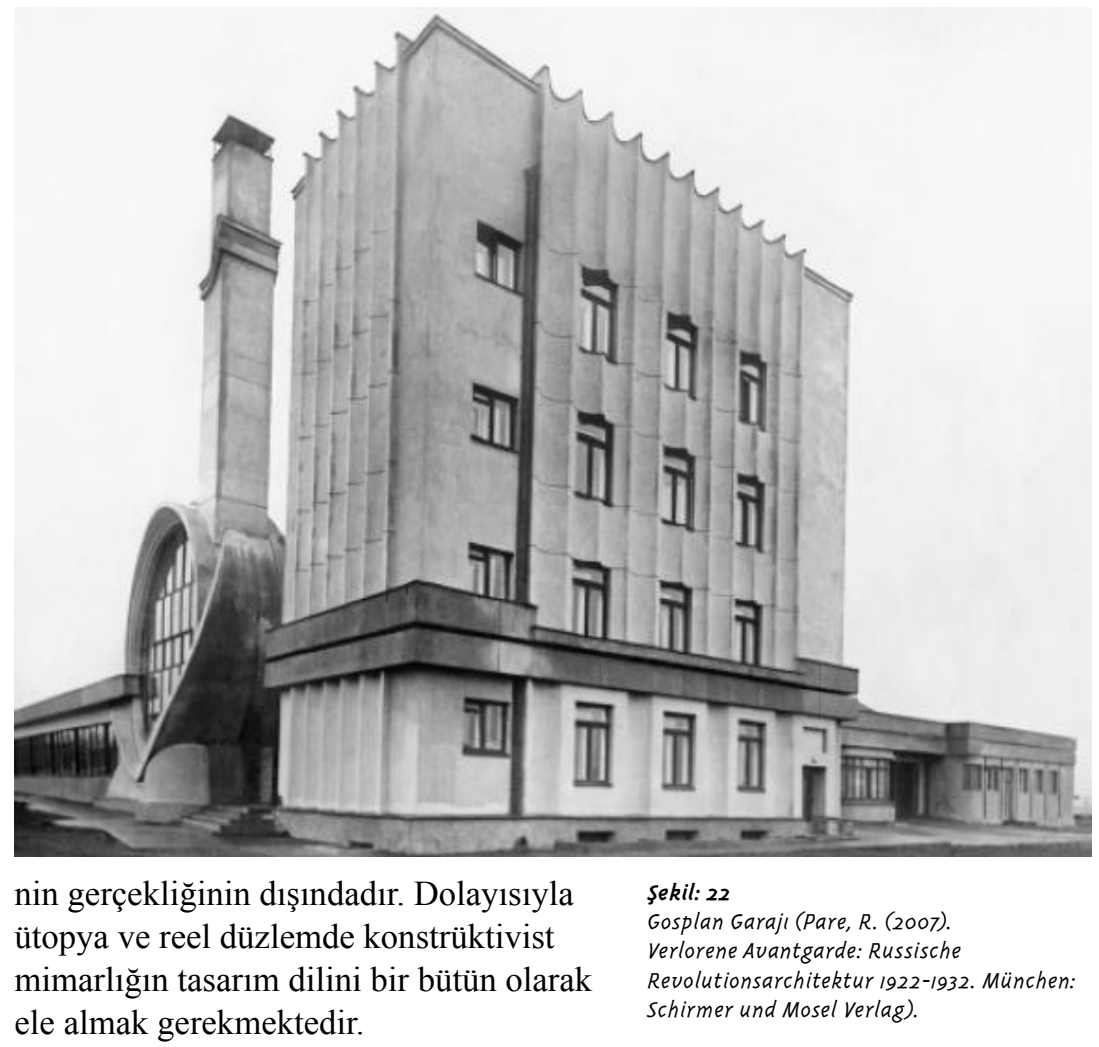

Melnikov'un kendini mimarlık kariyeri süresince konstrüktivist olarak tanımlamaması, ASNOVA ile OSA arasındaki kamplaşmada ASNOVA üyesi olmasına rağmen tarafsız kalması nedeniyle tasarımları ve inşa ettiği yapılar konstrüktivist mimarlık kapsamında ele alınıp alınamayacağı bir tartışma konusu olmaya devam etmektedir. Bu yaklaşım konstrüktivist mimarlı̆̆ın bir bütün olarak değerlendirilememesinden, sanat ve mimarlık ortamının birbirinden bağımsız, Melnikov'un ise S.S.C.B'nin sanat ve mimarlık ortamından izole bir karakter olarak görülmesinden kaynaklanmaktadır. Melnikov kaleme aldığı yazılarında Vladimir Tatlin'in çalışmalarını onayladığını, Alexander Rodchenko'nun kimseye benzemeyen özel bir sanatçı olduğunu ifade etmiş, Vesnin Kardeşleri projelerine ithafen "üç cesur" olarak adlandırmıştır (Hohrjakov, 2015). Söz konusu verilere dayanarak kendi özgün modernist yaklaşımını geliştiren Melnikov'un konstrüktivistlerden etkilenmediğini ifade etmek olanaksızdır.

Melnikov gibi doğrudan konstrükvist gruba katılmayan fakat konstrüktivist 
Şekil: 23

Moskova Enerji Santrali Kazan Dairesi Binasi (Pare, R. (2007). Verlorene Avantgarde: Russische Revolutionsarchitektur 1922-1932. München: Schirmer und Mosel Verlag).

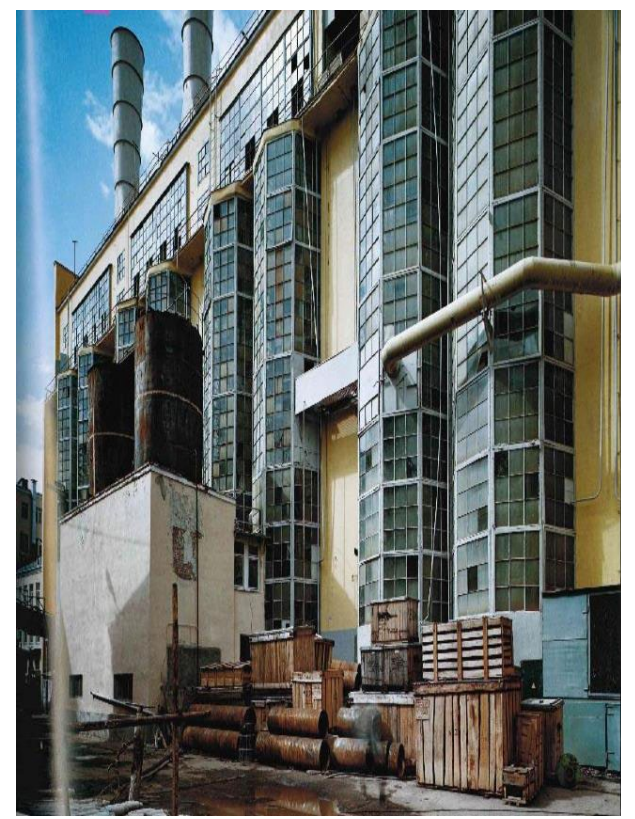

mimarlığın teorisini ve pratiğini eleştirmesine karşın konstrüktivist yapılar inşa eden mimarların sayısı S.S.C.B'de oldukça fazladır. Mimaride geleneksel yaklaşımı savunan RKP tarafindan Moskova'nın mimarisini ve kent planını şekillendirmekle görevli olan büronun başına getirilen Ivan Zholtovsky örnek olarak gösterilebilir. Geleneksel yaklaşımın S.S.C.B'deki öncülerinden biri olan, OSA ve ASNOVA gruplarına karşı aynı anda teorik düzlemde savaş veren Zholtovsky'nin endüstriyel yapıların tasarımında konstrüktivist yaklaşımın benimsenebileceğini kabul ederek Moskova Enerji Santrali'nin Kazan Dairesi Binasını inşa etmesi Zholtovsky'nin teorilerinin konstrüktivistler tarafından çürütüldüğü anlamina gelmektedir (Khan-Magomedov, 1987) (SSekil 23). Zholtovsky'nin Sovyet modenizmi ile uzlaşması ve konstrüktivistlerin zafer kazanmasının sonucunda Nikolai Kolli gibi mimarlar konstrüktivist gruba dahil olmuştur. Bu gelişme teorik düzlemde de konstrüktivistlerin rasyonalistlerin önüne geçmesini sağlamıştır.

Konstrüktivizmin Moskova merkezli olarak S.S.C.B coğrafyasına yayılmasına ve devrim mimarlığına dönüşmesine rağmen konstrüktivistlerin mimari yaklaşı$\mathrm{m} ı$ belirleyemediği tek kentin mimarların geleneksel yaklaşımı savunması nedeniyle St. Petersburg/Leningrad olduğu ifade edilebilir. Ancak OSA mimarlarının ülke çapında etkilerini hissettirmesinin sonucunda Gorki Kültür Sarayı'nı inşa eden Alexander Gegello ve David Kriechevsky, Georgi Simonov, Noi Trotsky olmak üzere Leningradlı konstrüktivistler inşa ettikleri yapilarla St. Petersburg'da modernizmi bir seçenek haline getirmişlerdir.

Georgi Simonov'un 1917 Ekim Devrimi'nin 10. Yıl dönümü anısına inşa ettiği okul yapısı ve Noi Trotsky'nin 1934 yılında inşasını tamamladığı Sovyetler Evi tasarımları hem reel düzlemde inşa edilen yapılar hem ütopya düzleminde değerlendirilen tasarımlar ile ilişsilendirilebilir. Simonov'un tasarımında okul yapısı basit geometrik formların kompozisyonundan oluşmakta, laboratuvarlar, spor salonu ve kıyafet değiştirmek için kullanılan odalar ana blokta, sınıflar ise görece daha küçük olan bir diğer blokta yer almaktadır (Şekil 24). Kat planları çekiç ve orak referans alınarak yapılmıştır. Noi Trotsky tarafından tasarlanan Sovyetler Evi'nin yatay pencere şeritleri ile tanımlanan uzun, dört katlı bloğunun bir kanadı yuvarlak cephe ile sonlanmakta diğer kanadında ise 10 katlı köşe balkonları bulunan kule yer almaktadır. Her iki yapıda da ütopya mimarlığı kapsamında değerlendirilen tasarımlardaki biçimsel dinamizmin izlerini görmek mümkündür (Şekil 25).

1923 yılında Emek Sarayı için düzenlenen mimarlık yarışmasından 1934 yılına uzanan süreçte konstrüktivistler, sadece ütopya düzleminde var olabilecek fikirleri reel düzleme taşımayı başarmakla kalmamış, sosyalist düzenin, devrimin karakteristik yapılarını inşa ederek yeni bir yaşamı mimari yapılar aracılığıyla kurgulamayı başarmışlardır. Ütopya düzleminde değerlendirilen tasarımlarda tektonik soyut imgeler, analojiler ve gelişmiş teknolojik donanım ile karşılık bulurken inşa edilen yapılarda kimi zaman yapının fiziksel görünümünün bir sembol aracı olarak yarattığ 1 vurgu kimi zaman ise içinde barındırdığı mekânların organizasyonu ve işlevsel birlikteliğinin sosyalist propagandaya hizmet edebilirliği üzerinden karşılık bulmaktadır. Bu durum tektonik, faktura ve 

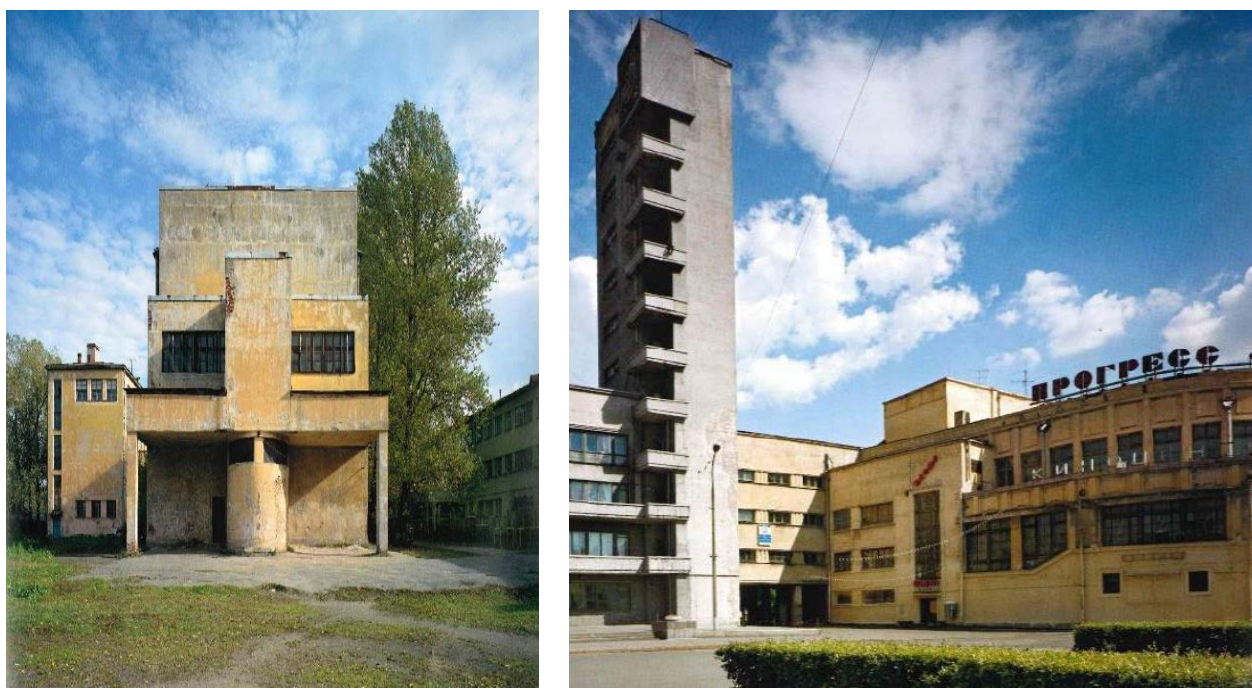

konstrüksiyonun birbirinden ayrı düşünülemeyecek birleşimleri ile yakından ilişkilidir. Faktura, malzeme seçimi üzerinden hem konstrüksiyonun bir parçası olmayı sürdürürken, hem de yarattı̆̆ 1 şeffaflık, soyut ve teknolojik simgesel anlamlar ile tektoniğin sosyalist düşünceyi yansıtma kurgusuna katkı sağlar. İnşa edilen işçi kulüpleri, komün evi, kültür sarayları konut yapıları, gazete veya okul binalarına kadar uzanan farklı mekân kurguları temelinde hem işlevsel olarak sahip oldukları sosyalizm düşüncesine hizmet eden fonksiyonlara sahip mekânlarıly (tektonik), hem bu mekânları inşa etmek üzere seçilmiş uygun malzeme kullanımlarıyla (faktura) hem de sonuç ürünün ortaya çıkardığı karakteristik ve sembolik biçimlenişiyle (konstrüksiyon), ütopik tasarımların temelini oluşturan üç disiplini bünyesinde taşımaya devam eder. $\mathrm{Bu}$ durum Sovyet modernizmi kapsamında değerlendirilen konstrüktivist mimarlığın örneklerinin sosyalist düzenin karakterini yansitan mimarlık tarihindeki ilk yapılar olma özelliğini ortaya koyarken, ütopya ve reel olmak üzere her iki düzlemde de konstrüktivist mimarlığa hayat veren üç disiplinin karşı1lı bulduğunu kanıtlamaktadır.

\section{Sonuç}

Vladimir Tatlin'in sanatın belirli bir zaman ve mekâna sıkıştırılması düşüncesine karşı çıkarak sanatı insanın var olduğu zamanın, mekânın ve gündelik hayatın bir parçası haline getirme düşüncesi ile endüstriyel malzemeler kullanarak tamamladığı rölyef çalışmaları, konstrüktivist mimarlığın devrim mimarlığına evrilme sürecinin başlangıç noktasını oluşturmaktadır. Tatlin'in fikirlerinin Ekim Devrimi'nden önce şekillendiği göz önünde bulundurulduğunda, Tatlin'in diğer avangard sanatç1lar gibi sanatı siyasetle ilişkilendirmeden özerk dünyasında değerlendirdiği açıktır. 1917 Ekim Devrimi’nin ardından sanatı üretim, sanatçıyı üretici ile özdeşleştirerek Tatlin'in sanatçının ülkenin kalkınmasında, endüstriyel üretiminde büyük bir rolü olduğunu ifade ederek sanatına sosyalist bir kimlik kazandırdığı anlaşılmaktadır.

Buna karşın 1920 yılında inşa edilmesi imkansız, dönemin teknolojik imkanlarının ötesinde bir donanıma sahip III. Enternasyonal Anitı'nı tasarlaması, toplumun ihtiyaçlarını ve nesnel koşulları referans almaksızın ideal olanı araması Tatlin'in fikirlerindeki değişimin teorik düzlemde kaldığını ve pratiğe yansımadığını göstermektedir. Bu durum sadece Tatlin için değil ütopya düzleminde konstrüktivist mimari tasarımları yapan Rodchenko, Klutsis, Lissitzky, Popova ve diğer avangard sanatçılar için de geçerlidir. Teori ile pratik arasındaki söz konusu çelişki, RKP kadrolarının konstrüktivistlere ve avangard sanatçılara getirdikleri eleştirinin en önemli nedenidir.

Diğer yandan III. Enternasyonal Anitı örneğinde somutlaşan tektonik, faktura
Şekil: 24

St. Petersburg Okul Yapisı (Pare, $R$. (2007). Verlorene Avantgarde: Russische Revolutionsarchitektur 1922-1932. München: schirmer und Mosel Verlag).

şekil: 25

Sovyetler Evi (Pare, R. (2007)

Verlorene Avantgarde: Russische Revolutionsarchitektur 1922-1932. München: schirmer und Mosel Verlag). 
ve konstrüksiyon disiplinleri, kullanılan endüstriyel malzemeler ve eklemlenen teknolojik donanımla mimari yapının anıtsal bir makineye, propaganda yapan canlı bir organizmaya dönüşme ve deneyimlenebilecek mekânlar sunma düşüncesi mimarları etkilemiş ve Tatlin'in tasarımı bir referans noktası haline gelmiştir. 1922 yılına uzanan süreçte konstrüktivizmin teorik zemininin oluşması, Konstrüktivistlerin Birinci Çalışma Grubu'nun programını yayımlanması, Vkhutemas'ın eğitim programının Tatlin'in fikirlerine içkin olması ve Vkhutemas'ta eğitimci olan Alexander Vesnin, Lyobov Popova ve Alexander Rodchenko gibi isimlerin kendilerini konstrüktivist olarak tanımlamaya başlaması, konstrüktivizm akımının yükseleceği zemini hazırlamıştır. Ütopya düzleminde değerlendirilen örnekler III. Enternasyonal Anıtı'nın taklidi olmanın ötesine geçerek, aşamalı olarak gelişmiş, sanatçılar ve mimarlar tektonik, faktura ve konstrüksiyon disiplinleri arasındaki ilişkiyi kendi perspektifleri ile yorumlayarak farklı amaçlara hizmet eden yapılar tasarlamış, mekânlar yaratmış ve kendi ütopyalarını gerçekleştirmeye çalışmışlardır. Söz konusu tasarımlar uygulanmamasına karşın konstrüktivistlerin geliştirdiği yaklaşım Vesnin Kardeşler tarafından uygulanabilir bir zemine taşınmış, Ginzburg'un Style and Epoch çalışması ve 1925 yılında OSA'nın kurulması ile birlikte konstrüktivist mimarlık, devrim mimarlı̆̆ının inşası için bir seçeneğe dönüşmüştür.

Tektonik, faktura ve konstrüksiyon disiplinlerini, makinenin yapısı ile mimarlık arasındaki ilişkiyi; sosyalist düzeni, işçi sınıfını ve toplumun ihtiyaçlarını referans alarak yeniden yorumlayan konstrükvistler, 1923 - 1934 yılları arasında işçi kulüpleri, kültür sarayları, konut yapıları, komün evi, kamu yapıları ve endüstriyel yapılar başta olmak üzere inşa ettikleri mimari yapılarla konstrüktivist mimarlık mirasının örneklerini oluşturmuşlardır. Ütopya mimarlığının sadece kağıt üzerinde değil, reel düzlemde gerçekleştirilebileceğini somut örneklerle gösteren konstrüktivistler, kısıtlı imkanlara rağmen alternatif bir mimarlığın var olabileceğini kanıtlamışlardır. Sovyet modernizmi kapsamında değerlendirilen konstrüktivist yapılar eşit, sınıfsız bir toplum yaratma yolunda ortaya koyulmuş, teorik ve sosyal bileşenleri içeren mekânsal organizasyonları, yapı tipolojileri ve biçimlenişleriyle modernist örneklerden farklı bir düzlemde sosyalist düzenin ilk ve özgün yapıları olarak mimarlık tarihindeki yerlerini almışlardır• 


\section{Kaynakça}

Anderson, R. (2015). Russia: Modern Architectures in History. London: Reaktion Books.

Bann, S. (1990). The Tradition Of Constructivism. New York: Ingram Publisher Services.

Barooshian, V. D. (1976). Vkhutemas and Constructivism. The Soviet and Post-Soviet Review, 197-207.

Bokov, A. (2017). Soviet Workers Clubs: Lessons from the Social Condensers. The Journal of Architecture, 403-436.

Bokov, A. (2014). Vkhutemas Training. Pavilion of the Russian Federation at the 14th International Architecture Exhibition la Biennale di Venezia, $5-33$.

Bowlt, J. E. (2017). Russian Art of the Avant - Garde: Theory and Criticism. London: Thamed and Hudson.

Buchli, V. (1998). Moisei Ginzburg's Narkomfin Communal House in Moscow: Contesting the Social and Material World. Journal of the Society of Architectural Historians, 160-181.

Carr, E. H. (2011). Bolsevik Devrimi 1917-1923 Cilt I. İstanbul: Metis Yayıncılık. Cheredina, I. S (2007). An architect who could design anything: On the 125th anniversary of the birth of Academician V. A. Vesnin. Herald of the Russian Academy of Sciences.

Chernikhov, I. (1933). Arkhitekturnye fantazii. 101 kompozitsiya. Leningrad: Mezhdunarodnaya kniga.

Cooke, C. (1990). Architectural Drawings of the Russian Avant-Garde. New York: Museum of Modern Art

Cooke, C., \& Ageros, J. (1991). The Avant-garde; Russian Architecture in Twenties. London: Academy Editions.

Çernișevski, N. (2012). Sanatın Gerçeklikle Estetik Ilişskileri. İstanbul: Kor Yayınları.

Dabrovski, M. (1991). Liubov Popova. Harry N Abrams Inc.

Davies, C. (2006). Key Houses of the Twentieth Century: Plans, Sections and Elevations. London: Laurence King Publishing.

Ginzburg, M. (1982). Style and Epoch. London: MIT Press.

Godi, O. (2015). Doeas a futurist architecture exist? Bergamo: Luoghi di Relazione associazione culturale.

Gray, C. (2000). The Rusian Experiment in Art -1863-1922. London: Thomas\& Hudson.

Harrison, C., \& Wood, P. (2003). Art in theory, 1900 2000: an anthology of changing ideas. Malden: Blackwell Publication.

Honda, A. (2017). A New Vision in Architecture: Ivan Leonidov"s Architectural Projects Between 1927 - 1930. Waseda University Press, 79-94.

Hohrjakov, V. (2015). Konstantin Melnikov ja avantgardistin muotukova. Los Angeles: SPA.

Jangfeldt, B. (1976). Majakovskij and Futurism 1917-1921. Upsala: Almqvist \& Wiksell.

Khan-Magomedov, S. (1987). Pioneers of Soviet Architecture: The Search for New Solutions in the 1920s and 1930s. Random House Incorporated.

Lunaçarski, A. (2004). Devrim ve Sanat. İstanbul: İnter Yayınları.

Margolin, V. (2012). Ütopya Mücadelesi. İstanbul: Espas Kuram Sanat Yayınları.

Mikadze, M. (2012). Narkomfin: A Sealed Key to the Utopia. (Bachelor Degree Dissertation). London
Metropolitan University, London.

Nakov, A. (1986). AVANT-GARDE RUSSE. Newyork: Universe Books.

Nisbet, J. (2010). Material Propositions on the Individual/ Collective: The Work of Vladimir Tatlin. Modernism/modernity, 109-134.

Palmer, A. L. (2016). Historical Dictionary of Architecture. London: Rowman\&Littlefield.

Pare, R. (2007). Verlorene Avantgarde: Russische Revolutionsarchitektur 1922-1932. München: Schirmer und Mosel Verlag.

Railing, P. (1994). Russian Avant-Garde art and the new Society: In the Context of D. Shterenberg's 'report of the activities of the section of plastic arts of Narkompros' of 1919. Revolutionary Russia, 7(1), 38-77.

Rickey, G. (1967). Constructivism: Origins and. Evolution. New York: Braziller.

Urban, F. (2012). Tower and Slab: Histories of Global Mass Housing. Oxon: Routledge.

Vesnin, A., \& Ginzburg, M. (1927). Sovremennaya Arkhitektura. 